\title{
Mitochondrial disorders and the eye
}

This article was published in the following Dove Press journal:

Eye and Brain

26 September 2011

Number of times this article has been viewed

\section{Nicole J Van Bergen \\ Rahul Chakrabarti \\ Evelyn C O'Neill \\ Jonathan G Crowston \\ Ian A Trounce}

Centre for Eye Research Australia, Department of Ophthalmology, University of Melbourne, Victoria, Australia
Correspondence: lan A Trounce

Centre for Eye Research Australia, Department of Ophthalmology, University of Melbourne, Royal Victorian Eye and Ear Hospital, 32 Gisborne Street, East Melbourne, Victoria, Australia 3002 Tel +61399298160

Fax +6I39662 3859

Email i.trounce@unimelb.edu.au
Abstract: The clinical significance of disturbed mitochondrial function in the eye has emerged since mitochondrial DNA (mtDNA) mutation was described in Leber's hereditary optic neuropathy. The spectrum of mitochondrial dysfunction has become apparent through increased understanding of the contribution of nuclear and somatic mtDNA mutations to mitochondrial dynamics and function. Common ophthalmic manifestations of mitochondrial dysfunction include optic atrophy, pigmentary retinopathy, and ophthalmoplegia. The majority of patients with ocular manifestations of mitochondrial disease also have variable central and peripheral nervous system involvement. Mitochondrial dysfunction has recently been associated with agerelated retinal disease including macular degeneration and glaucoma. Therefore, therapeutic targets directed at promoting mitochondrial biogenesis and function offer a potential to both preserve retinal function and attenuate neurodegenerative processes.

Keywords: mitochondria, disease, retina, eye, aging, neuroprotection

\section{Introduction}

The importance of optimal mitochondrial function for ocular health has been clear since the first mitochondrial DNA (mtDNA) disease mutation was discovered in Leber's hereditary optic neuropathy (LHON). ${ }^{1}$ Other syndromic mtDNA diseases often have retinal involvement together with variable central nervous system pathology. A second major disease grouping classified as "mitochondrial" disease is due to mutations in nuclear genes that result in mitochondrial dysfunction, including autosomal dominant optic atrophy (ADOA), Friedreich's ataxia, Mohr-Tranebjaerg syndrome, and Charcot-Marie-Tooth disease subtype CMT2A. These disorders commonly display optic neuropathy together with variable central nervous system involvement, and have been described in detail elsewhere. ${ }^{2,3}$ The neuro-ophthalmic manifestations of mitochondrial diseases have also been extensively reviewed by Newman et al. ${ }^{4}$

With our increased awareness, the spectrum of "mitochondrial disease" has expanded from describing mtDNA disease, to diseases secondary to improper function of any protein located in the organelle resulting in abnormal mitochondrial function. Moreover, mitochondrial dysfunction is attracting growing attention as contributing to the pathogenesis of many common sporadic age-related neurodegenerative diseases, including Alzheimer's disease, Parkinson's disease, and glaucoma. ${ }^{5-8}$ While controversy exists as to whether mitochondrial impairment in these diseases is primary or secondary to upstream disease pathways, the mitochondrion is emerging as pivotal in disease pathogenesis and as an important target of novel therapeutic approaches. 
The eye can therefore be viewed as a model for energetic impairment in the central nervous system, often being the first neuronal tissue affected by mitochondrial failure. The eye may become a model of therapeutic experimentation, with direct implications for degenerative brain diseases. Here we discuss the variable ocular involvement in inherited mitochondrial diseases, the possible role of mitochondrial dysfunction in the common age-related ophthalmic diseases, including glaucoma and age-related macular degeneration, and finally we review emerging therapeutic approaches to improving mitochondrial function.

\section{Mitochondria and neurons}

The accurate cliché of the mitochondrion being the "powerhouse of the cell" has been complicated by the growing recognition that this organelle is a central node of key cellular pathways governing not only intermediary metabolism, but also stress responses and cell death. ${ }^{9}$ We first consider the traditional energetic role of the organelle and the effects on retinal neurons resulting from mtDNA mutations.

Neurons require large amounts of adenosine triphosphate (ATP) supplied by the mitochondria. Energetic needs are greatest at dendritic regions where ATP-dependent ion pumping reinstates the plasma membrane electrical potential consequent to impulse transmission. ${ }^{10}$ Neuronal anatomy, with long processes extending from the cell body where mitochondria are synthesized, requires the purposeful transport of organelles along axons and dendrites to the sites of ATP usage. This transport is accomplished by energydependent bidirectional transport along microtubules. Kinesin moves mitochondria in the anterograde direction, whereas retrograde transport is via dynein motors. ${ }^{11}$ Mitochondrial network dynamics is a growing area in mitochondrial research, with the discovery of genes involved in the constant fission and fusion of organelles. The optic atrophy 1 (autosomal dominant) gene (OPA1), the most common gene mutated in ADOA, encodes a dynamin-related GTPase of the mitochondrial inner membrane that directs fusion of this membrane. Why disruption of mitochondrial dynamics due to loss of OPA1 function results in specific loss of retinal ganglion cells remains unknown.

The simplistic idea that different degrees of energetic impairment lead to a hierarchy of neuronal populations being adversely affected does not adequately explain the pathological changes in the central nervous system in mitochondrial diseases. Retinal ganglion cells appear to be one of the most sensitive neurons to mitochondrial failure, although the reasons for this susceptibility remain unclear.

\section{mtDNA and oxidative phosphorylation}

Mitochondrial DNA is a circular, double-stranded DNA molecule residing in the mitochondrial matrix. It is the only non-nuclear DNA in mammalian cells, coding 13 of the approximately 90 protein subunits of the oxidative phosphorylation complexes. The majority of the protein machinery required for mitochondrial replication, transcription, translation, and assembly is encoded by nuclear genes, ${ }^{12}$ whilst mtDNA contributes a 12SrRNA, a 16SrRNA, and 22 tRNAs. ${ }^{13}$ The oxidative phosphorylation pathway produces the majority of ATP for use in all cells. It comprises five multisubunit enzyme complexes: complex I, the NADH:ubiquinone oxidoreductase ( $>45$ subunits, seven from mtDNA); complex II, the succinate dehydrogenase (four nuclear subunits); complex III, the ubiquinone:cytochrome c oxidoreductase (11 subunits, one from mtDNA); complex IV, cytochrome c oxidase (13 subunits, three from mtDNA); and complex V, $\mathrm{H}^{+}$ATPsynthase (15 subunits, two from mtDNA). Electrons enter the respiratory chain at either complex I from the oxidation of NADH or complex II from oxidation of $\mathrm{FADH}_{2}$. As pairs of electrons travel via redox centers in complexes I, III, and IV, protons are extruded into the intermembrane space where the proton gradient is harnessed by complex V to phosphorylate ADP to ATP. ${ }^{14}$

Dysfunction of oxidative phosphorylation consequent to mtDNA or nuclear gene mutations can result in a reduction in maximal ATP production rate and increased reactive oxygen species production by complexes I and III, ${ }^{15,16}$ heightening oxidative stress within the cell. ${ }^{17}$ mtDNA is highly susceptible to damage by reactive oxygen species due in part to the lack of protective DNA binding histones, ${ }^{18}$ limited DNA repair mechanisms, ${ }^{19,20}$ and the close proximity of mtDNA to the site of production of reactive oxygen species, the oxidative phosphorylation machinery. And unlike nuclear genes, mtDNA exists in hundreds to thousands of copies per cell, is replicated throughout life, and is maternally inherited. The extent to which mtDNA mutations produce pathologic changes in tissues depends on the balance between normal and mutant mtDNA populations in cells and tissues (heteroplasmy) and the resilience of tissues to impairment of oxidative phosphorylation (threshold effect), resulting in varied phenotypes and affected tissues in mitochondrial diseases. ${ }^{21,22}$ The differential expression of components of the electron transport chain in various tissues and the segregation of mitochondria during development ${ }^{23}$ has also been implicated in tissue-specific diseases. ${ }^{24}$ 


\section{mtDNA haplogroups}

The mtDNA genome accumulates mutations at a much higher rate than nuclear DNA, and during human evolution certain mutation groups (haplogroups) have evolved and become fixed in specific populations. ${ }^{25} \mathrm{~A}$ haplogroup is a cluster of stable background mtDNA polymorphisms in individuals from a common female ancestor. ${ }^{26}$ Specific mtDNA haplogroups have been associated with pseudoexfoliative glaucoma, ${ }^{27,28}$ primary angle-closure glaucoma, ${ }^{29}$ age-related macular degeneration, ${ }^{30-32}$ and LHON. ${ }^{32-40}$

The implication of these associations is that the mtDNA sequence background may influence the clinical phenotype of a disease by subtle effects on oxidative phosphorylation function. ${ }^{40}$ Interestingly, haplogroup associations in healthy populations have been demonstrated to influence maximum oxygen consumption, where healthy males carrying haplogroup $\mathrm{J}$ had lower efficiency of the electron transport chain and ATP production, ${ }^{41}$ which may explain the increased prevalence of the J haplogroup in LHON patients. ${ }^{40}$ At a molecular level, the haplogroup may influence the cellular response to stress, because LHON cells with point mutations m.11778G $>$ A or m.14484T $>$ C from mtDNA haplogroup $\mathrm{J}$ had markedly increased susceptibility to a neurotoxic metabolite compared with the same mutations on different mtDNA haplogroup backgrounds, such as the $\mathrm{U}$ and $\mathrm{H}$ haplogroups. ${ }^{42}$ Certain haplogroups also delay the assembly kinetics of complexes I, II, and IV into oxidative phosphorylation supercomplexes ${ }^{43}$ where this cooperative stability is required to maintain efficient respiration. ${ }^{44}$

\section{Mitochondrial dynamics}

If mitochondrial distribution in neurons is impaired, local energetic crisis may occur even if oxidative phosphorylation remains optimal. Within the eye, the optic nerve is structurally unique, consisting of retinal ganglion cell axons originating in the unmyelinated retinal nerve fiber layer which turn 90 degrees through a series of perforated collagen plates, known as the lamina cribrosa, at the optic nerve head, where mitochondrial density decreases as myelination begins. ${ }^{45-51}$

Mitochondrial shape and distribution are regulated by two opposing processes, ie, fission and fusion. Fission is mediated by dynamin-related protein 1 and fission 1 (mitochondrial outer membrane) homolog (Saccharomyces cerevisiae), whilst fusion is regulated by OPA1, mitofusin-1, and mitofusin- 2 . These processes are vital to maintain adequate mixtures of mtDNA $^{52,53}$ and to respond to localized metabolic demands. ${ }^{54}$ Changes in the expression of fission/fusion proteins alter mitochondrial shape and size, and may promote or inhibit apoptotic signals leading to neuronal death. Neuronal cells have markedly high expression levels of dynamin-related protein 1 and OPA1 compared with non-neuronal cells. ${ }^{55}$ Furthermore, knockdown of endogenous dynamin-related protein 1 significantly increases the mitochondrial length in all cell types, but only selectively causes apoptosis of cortical neurons, ${ }^{55}$ indicating the sensitivity of specific neuronal populations to loss of control of mitochondrial dynamics.

Mitochondrial fission/fusion proteins and their regulators are associated with optic nerve loss. OPA1 mutation is the commonest cause of ADOA..$^{2-4}$ Mutations in the outer membrane profusion protein, mitofusin-2, in CharcotMarie-Tooth disease ${ }^{56,57}$ impair nerve conductive velocity in peripheral neurons, and lead to subacute optic atrophy in some pedigrees. ${ }^{58}$ Evidence is emerging that involvement of single nucleotide polymorphisms of mitofusin-1 and mitofusin- 2 genes is present in normal tension glaucoma. ${ }^{59}$ Presenilin-associated rhomboid-like protease (PARL) regulates mitochondrial fusion ${ }^{60}$ and processes OPA1 into a soluble form. ${ }^{61}$ The T191C genetic variation of PARL in normal populations exhibited significant effects on mitochondrial content levels. ${ }^{62}$ Single nucleotide polymorphisms of PARL have been associated with glaucoma, LHON, and mutations causing Parkinson's disease. ${ }^{59,63,64}$

Altering the fission-fusion balance has profound effects on mitochondrial function and structure. With pharmaceutical or genetic inhibition of fusion, there is a collapse of mitochondrial energy production as mitochondria consume ATP $^{65}$ which alters mitochondrial distribution toward fission, ${ }^{54,66}$ promoting apoptosis. ${ }^{65,67}$ Converse to mitochondrial fission, promoting mitochondrial fusion increases mitochondrial energy production ${ }^{68}$ which may be protective against injury ${ }^{69,70}$ Increased mitochondrial fusion has been demonstrated to protect cells from autophagy by boosting mitochondrial cristae volume and enhancing mitochondrial ATP synthase activity ${ }^{65}$ Upregulation of OPA1 in mouse models was protective against retinal ganglion cell death in a glaucoma mouse line, DBA2 $\mathrm{J}^{71}$ and may be an important cellular defense mechanism against glaucomatous optic neuropathy. ${ }^{72}$

\section{Mitochondrial diseases and optic neuropathies}

LHON is characterized by degeneration of retinal ganglion cells and their axons. LHON is the most common inherited mtDNA disease, and over $90 \%$ of cases are due to mutations in one of three mtDNA-encoded oxidative phosphorylation complex I genes, ie, G11778A/ND4, T14484C/ND6, and 
G3460A/ND1. ${ }^{2-4}$ These mtDNA mutations lead to decreased complex I enzyme rates ${ }^{73}$ and lowered ATP production, ${ }^{74}$ which are hypothesized to sensitize retinal ganglion cells to apoptosis. . $^{2,3}$ Patients typically have normal vision until the age of 15-35 years, when a rapid loss of central vision occurs in one eye, then the second eye within one year. Visual loss progresses to 20/200 or worse, with visual field testing revealing central or centrocecal scotomas. ${ }^{3}$ Axonal loss in the papillomacular bundle results in temporal atrophy of the optic nerve head. While maternal inheritance provides a strong diagnostic clue, penetrance of LHON is variable within kindreds, and males are overrepresented, with $80 \%-90 \%$ of affected individuals being male. ${ }^{4}$

ADOA, also known as Kjer's optic neuropathy, ${ }^{75}$ also leads to vision impairment due to selective and specific degeneration of retinal ganglion cells and their axons in the optic nerve. ${ }^{3,76,77}$ ADOA results from haploinsufficiency of the mitochondrial fusion protein, OPA $1 .{ }^{78}$ In ADOA, there is evidence of decreased mtDNA content ${ }^{79}$ and an increased prevalence of mtDNA mutations in severe cases of ADOA (ADOA+) where multiple deletions of mtDNA were identified. ${ }^{80,81}$ In addition to its role in maintaining mitochondrial cristae structure, ${ }^{68,82-84}$ other functions of OPA1 may include ensuring adequate "mixing" of mtDNA. ${ }^{54}$ Small hydrophobic peptide fragments from cleaved OPA1 may also contribute to mtDNA nucleoid attachment to the inner mitochondrial membrane, promoting mtDNA replication and distribution. ${ }^{85}$

Disrupted mtDNA distribution, or cristae structure, is predicted to have secondary impacts on oxidative phosphorylation due to either inadequate mtDNA transcription or lack of inner membrane surface area for oxidative phosphorylation complex anchoring. It has been reported that decreased oxidative phosphorylation capacity in ADOA patients with OPA1 mutations correlates with relatively poor visual acuities, while related mutation carriers with normal vision appeared to have relatively preserved oxidative phosphorylation function. ${ }^{86}$ This suggests that patients with preserved vision may harbor genetic variants that allow some compensation of oxidative phosphorylation function.

\section{Syndromic mtDNA diseases with ocular involvement Retinopathy}

Several syndromic central nervous system diseases are also known to result from mtDNA mutations. While optic neuropathy is an occasional finding in these disorders, a pigmentary retinopathy is the commonest retinal pathology.
This is best illustrated in the neurogenic atrophy and retinitis pigmentosa syndrome, which results from point mutations in the mtDNA ATPase-6 gene, commonly T8993G. Patients typically present with retinitis pigmentosa with or without optic neuropathy, and can develop dystonia. ${ }^{87}$ Mitochondrial encephalopathy, lactic acidosis, and stroke-like episodes (MELAS) can result from many mtDNA point mutations, although the most common is the A3243G mutation in the tRNA ${ }^{\text {Leu }}$ gene. MELAS patients present with strokelike episodes that lead to frequent retrochiasmal visual loss, but often also have pigmentary retinopathy without optic atrophy. ${ }^{88}$ The spectrum of disease arising from the A3243G point mutation is also evidenced by its contribution to the pathogenesis of maternally inherited diabetes and deafness. ${ }^{89,90}$ This is a multisystemic disease characterized by sensorineural deafness, retinal abnormalities, and diabetes, commonly arising in the third to fourth decade of life. ${ }^{89,91}$ The retinal abnormalities, typically occurring in maternally inherited diabetes and deafness, are bilateral in the majority of cases, and involve two main phenotypes, as described by Rath et al. ${ }^{92}$ The most common phenotype involves circumferential perifoveal atrophy with retinal pigment epithelium hyperpigmentation sparing of the fovea. The second phenotype is a pattern dystrophy characterized by relative sparing of the fovea, with diffuse granularity and pigment clumping, and retinal pigment epithelium within the retinal vascular arcades. However, despite the degree of atrophy, visual acuity is preserved, with a good prognosis..$^{93}$

\section{Chronic progressive external ophthalmoplegia}

Chronic progressive external ophthalmoplegia is a phenotype of mitochondrial myopathy with ophthalmic involvement. The presenting signs are of bilateral ptosis, which generally precedes development of ophthalmoplegia. Whilst visual acuity is preserved, progressive fibrosis of the extraocular muscles can manifest as diplopia. ${ }^{4}$ Eyelid muscles are also affected and can contribute to exposure-related corneal disease. Chronic progressive external ophthalmoplegia is attributed to sporadic mutations, nuclear inherited mutations, and maternally inherited mutations of mtDNA. Most cases of chronic progressive external ophthalmoplegia arise sporadically from large-scale rearrangement of mtDNA resulting in defective oxidative phosphorylation. ${ }^{4,94}$ Nuclear inherited chronic progressive external ophthalmoplegia is attributed to multiple large-scale mutations in mtDNA affecting mtDNA replication and repair. ${ }^{4}$ Maternally inherited chronic progressive external ophthalmoplegia 
commonly arises from point mutations in mtDNA tRNA genes. ${ }^{95}$ The Kearns-Sayre syndrome is the severest form of chronic progressive external ophthalmoplegia, where the presenting feature is usually ptosis and ophthalmoplegia. Kearns-Sayre patients often develop a pigmentary retinopathy together with cardiac conduction defects and severe neurological signs, including ataxia. ${ }^{96}$

\section{Mendelian mitochondrial syndromes with ocular involvement}

Several nuclear gene mitochondrial disorders have optic neuropathy as a secondary feature. These are considered briefly here because they result from mutations in mitochondrial proteins that indirectly interfere with oxidative phosphorylation, and so can add further insights into energetic failure and retinal pathogenesis.

Friedreich's ataxia results from a GAA trinucleotide repeat expansion in the frataxin gene. Frataxin is a mitochondrial protein involved in $\mathrm{Fe}-\mathrm{S}$ cluster assembly, disruption of which results in excessive mitochondrial iron levels and loss of retinal ganglion cells, giving rise to optic neuropathy and ataxia. ${ }^{2,4,97}$ The oxidative phosphorylation pathway relies on the redox ability of $\mathrm{Fe}$, via multiple $\mathrm{Fe}-\mathrm{S}$ clusters, to perform electron transfer and thus energy transduction. Four of the five oxidative phosphorylation complexes contain either or both heme prosthetic groups or Fe-S clusters. The pattern of retinal ganglion cell loss in Friedreich's ataxia is more diffuse than that seen in LHON and ADOA, not preferentially involving the papillomacular bundle but involving the optic radiations, and is slowly progressive. , $^{2,989}$

Mohr-Tranebjaerg syndrome is an X-linked recessive disease characterized by deafness, dystonia, and optic atrophy. ${ }^{100}$ It is caused by mutation of the deafness/ dystonia peptide, also called TIMM8A. ${ }^{101}$ TIMM8A is one of several proteins forming the translocase of the inner membrane complex, which together with the translocase of the outer membrane forms the machinery of mitochondrial protein import. ${ }^{102,103}$ Because the oxidative phosphorylation complexes are among the most abundant of mitochondrial proteins, perturbation of protein import is likely to impact on the oxidative phosphorylation pathway, although mitochondrial studies in patients have not yet been reported. Retinal ganglion cell loss appears to be similar to that reported for Friedreich's ataxia, with diffuse involvement of the optic radiations. ${ }^{104,105}$

Hereditary spastic paraplegia is a disease grouping that can result from mutations in a number of nuclear genes. It is characterized by progressive spasticity of the lower limbs, frequently complicated by the presence of optic atrophy. One of these variants is caused by mutations in the $S P G 7$ gene coding for paraplegin, an AAA-type metalloprotease of the mitochondrial inner membrane. Mutation of paraplegin has been reported to cause impairment of oxidative phosphorylation complex I, providing a pathogenetic link to LHON. ${ }^{106}$ Pathological descriptions of the optic nerve have not been reported.

As mentioned above, when discussing mitochondrial dynamics, Charcot-Marie-Tooth disease subtype CMT2A has been associated with mutations in the mitochondrial fusion protein, mitofusin-2. ${ }^{107}$ Charcot-Marie-Tooth disease is a common inherited peripheral neuropathy; the variant CMT2A also displays an optic neuropathy that typically develops a decade after onset of the neuropathy. Visual decline progresses rapidly, with bilateral central scotomas evident on fundus examination, reminiscent of LHON. ${ }^{2,4}$ Mitofusin-2 is a GTPase similar in structure to OPA1, but is located in the mitochondrial outer membrane. No consistent oxidative phosphorylation phenotype has been identified, although studies are limited. ${ }^{2}$ Pathological reports indicate a pattern of retinal ganglion cell loss similar to LHON, with preferential involvement of the papillomacular bundle. ${ }^{58}$

\section{Oxidative phosphorylation defects and preferential retinal ganglion cell pathology}

The very common but far from invariant finding of preferential retinal ganglion cell loss in mitochondrial diseases raises fascinating questions for pathogenesis. From the early "metabolic maps" provided by Kageyamia and Wong-Riley, ${ }^{48}$ who pioneered histochemical reaction for the oxidative phosphorylation complex IV (cytochrome oxidase) to map mitochondrial density in the retina, it was clear that inner segments of the photoreceptor have the highest degree of enzymatic activity, followed by the inner and outer plexiform layers and the cell bodies of the retinal ganglion cells, and their axons forming the nerve fiber layer. Yet only in a minority of mitochondrial disease patients are the photoreceptors affected, such as found in the pigmentary retinopathies seen in MELAS, neurogenic atrophy, and retinitis pigmentosa, and Kearns-Sayre syndromes. The lack of outer retinal involvement in ADOA and CMT2A, disorders of mitochondrial fission/fusion, is circumstantial evidence that only neurons with long axons suffer from disordered mitochondrial fission and fusion.

Within the mtDNA diseases, how can different defects in the same pathway (oxidative phosphorylation) most commonly give rise to loss of retinal ganglion cells, yet 
sometimes cause photoreceptor loss in the absence of optic neuropathy? This may in part be explained by the high metabolic activity of the retinal pigment epithelium which forms the retina-brain barrier and is richly endowed with mitochondria. ${ }^{10}$ Oxidative stress may be heightened by the high local oxygen concentrations due to proximity to the choroid and the daily outer segment phagocytosis by the retinal pigment epithelium that leads to accumulation of the phototoxin, $N$-retinyl- $N$-retinylidene ethanolamine. It is possible that the point mutations responsible for MELAS, neurogenic atrophy, and retinitis pigmentosa syndromes, and the mtDNA deletions associated with Kearns-Sayre syndrome/chronic progressive external ophthalmoplegia result in heightened oxidative stress compared with the LHON mutations. Experimentally, when retinal pigment epithelium oxidative phosphorylation is specifically ablated in postnatal mice using a cre-lox tFAM knockdown approach, the retinal pigment epithelium undergoes dedifferentiation and a secondary photoreceptor degeneration results. ${ }^{108}$ Histopathological studies in limited cases of mtDNA-linked pigmentary retinopathy suggest a secondary disruption of photoreceptors consequent to retinal pigment epithelium failure. ${ }^{4}$

Both LHON and ADOA can occur in more complex forms, with variable central nervous system involvement. Extraocular features of "LHON plus" syndromes include spastic dystonia, ataxia, or even more severe encephalopathies. It is interesting that mtDNA mutations identified in these cases are usually in complex I genes, are different from the primary LHON mutations, and have more severe defects in oxidative phosphorylation. ${ }^{109-111}$ It has become clear that ADOA can also be associated with extraocular features, with up to one in six OPA1-linked ADOA patients showing variable combinations of sensorineural deafness, ataxia, peripheral neuropathy, and ophthalmoplegia. ${ }^{112}$

The clinical and biochemical evidence therefore supports the concept that subtle oxidative phosphorylation defects, especially in complex I genes, result in preferential retinal ganglion cell loss. More severe oxidative phosphorylation defects result in more severe disease, typically affecting the brainstem, basal ganglia or cerebellum, with or without optic neuropathy. The common involvement of sensorineural deafness and peripheral neuropathy in such patients reiterates the theme of neurons with long axons being more vulnerable to mitochondrial dysfunction. Refer to Table 1 for a summary of mitochondrial disorders with ocular involvement which outlines the complexity of preferential retinal ganglion cell pathology.

\section{Age-related neurodegeneration, mitochondria, and the retina mtDNA somatic mutation, oxidative phosphorylation, and aging}

A lingering disadvantage of the semiautonomous nature of mitochondria in long-lived organisms is the necessity for continual replication of the mitochondrial genome. This leads to an age-related loss of mtDNA integrity, and a consequent decline in oxidative phosphorylation in postmitotic tissues. ${ }^{113,114}$ mtDNA is highly susceptible to damage from reactive oxygen species due to lack of DNA repair and protection mechanisms. ${ }^{18,20}$ Acquired mtDNA mutations through aging and oxidative stress are increasingly being attributed to diseases of the aging eye and brain. ${ }^{115,116}$ Evidence of increased point mutations, large-scale rearrangements, and mtDNA depletions has been demonstrated in age-related macular degeneration, subtypes of ADOA, and subtypes of glaucoma.

In subtypes of glaucoma, there is evidence of increased mtDNA mutations in peripheral blood and the trabecular meshwork, particularly in patients with primary open angle glaucoma, ${ }^{11-119}$ pseudoexfoliation glaucoma, ${ }^{105}$ and congenital glaucoma. ${ }^{120}$ Interestingly, mtDNA mutations did not occur, or were in very low abundance in other glaucoma subtypes (pigmented, juvenile, acute, neovascular, and chronic closed angle glaucoma), ${ }^{119,121}$ once again highlighting a combination of risk factors precipitating retinal ganglion cell loss.

Mouse models that accumulate high levels of mtDNA mutations owing to impairments in mitochondrial polymerase $\gamma$ proofreading function have been shown to develop phenotypes consistent with accelerated aging. Our group recently demonstrated that mice with neuronal-specific mitochondrial polymerase $\gamma$ mutations have increased mtDNA deletions and point mutations in their retinas, which increase the sensitivity of the retinal ganglion cell-dominant inner retinal function to acute intraocular pressure injury. ${ }^{122}$ This insult is known to produce mechanical, metabolic, and oxidative stress in the retina. ${ }^{7}$ These findings indicate that an accumulation of mtDNA mutations is associated with impairment in neural function and reduced capacity of neurons to resist external stress in vivo, suggesting a potential mechanism whereby the aging central nervous system can become more vulnerable to neurodegeneration.

\section{Glaucoma}

Glaucoma is a neurodegenerative disease of the optic nerve characterized by accelerated death of retinal ganglion cells and their axons, leading to progressive visual field loss. 
Table I Mitochondrial diseases with ocular involvement

\begin{tabular}{|c|c|c|c|c|c|}
\hline Disease & Mutation & $\begin{array}{l}\text { Impact on } \\
\text { mitochondrial function }\end{array}$ & Ocular phenotype & $\begin{array}{l}\text { Retinal } \\
\text { ganglion } \\
\text { cell affected? }\end{array}$ & $\begin{array}{l}\text { Photoreceptor } \\
\text { affected? }\end{array}$ \\
\hline $\begin{array}{l}\text { Leber's hereditary } \\
\text { optic neuropathy }\end{array}$ & $\begin{array}{l}\text { mtDNA encoded } \\
\text { complex I subunits } \\
\text { NDI, } 4,6\end{array}$ & $\begin{array}{l}\text { OXPHOS complex I } \\
\text { defects }\end{array}$ & $\begin{array}{l}\text { Central or centrocecal } \\
\text { scotomas and axonal loss in the } \\
\text { papillomacular bundle of rapid } \\
\text { onset; temporal atrophy } \\
\text { of the optic nerve head }\end{array}$ & Yes & No \\
\hline $\begin{array}{l}\text { Autosomal dominant } \\
\text { optic atrophy }\end{array}$ & $\begin{array}{l}\text { Over } 220 \text { mutations } \\
\text { identified, primarily } \\
\text { in Opal gene }\end{array}$ & $\begin{array}{l}\text { Regulation of cristae } \\
\text { morphology and } \\
\text { OXPHOS impairment }\end{array}$ & $\begin{array}{l}\text { Insidious onset, slowly } \\
\text { progressive disease with } \\
\text { bilateral vision loss; central, } \\
\text { centrocecal, paracentral } \\
\text { scotomas, and generalized } \\
\text { color-perception deficits }\end{array}$ & Yes & No \\
\hline $\begin{array}{l}\text { Neurogenic atrophy } \\
\text { and retinitis } \\
\text { pigmentosa syndrome }\end{array}$ & $\begin{array}{l}\text { mtDNA mutation } \\
\text { most commonly } \\
\text { T8993G in } \\
\text { ATPase-6 gene }\end{array}$ & $\begin{array}{l}\text { OXPHOS complex V } \\
\text { defect }\end{array}$ & $\begin{array}{l}\text { Retinitis pigmentosa, cone-rod } \\
\text { photoreceptor dystrophy, with } \\
\text { or without optic neuropathy }\end{array}$ & Yes & Yes \\
\hline $\begin{array}{l}\text { Mitochondrial } \\
\text { encephalopathy, } \\
\text { lactic acidosis and } \\
\text { stroke-like episodes }\end{array}$ & $\begin{array}{l}\text { Most commonly } \\
\text { A3243G mtDNA } \\
\text { mutation in the } \\
\text { tRNA }{ }^{\text {Leu }} \text { gene }\end{array}$ & $\begin{array}{l}\text { Multiple OXPHOS } \\
\text { defects }\end{array}$ & $\begin{array}{l}\text { Stroke-like episodes, } \\
\text { retrochiasmal visual loss, } \\
\text { pigmentary retinopathy } \\
\text { without optic atrophy }\end{array}$ & No & Yes \\
\hline $\begin{array}{l}\text { Maternally } \\
\text { inherited diabetes } \\
\text { and deafness (MIDD) }\end{array}$ & $\begin{array}{l}\text { Most commonly } \\
\text { A3243G mtDNA } \\
\text { mutation in the } \\
\text { tRNA } \\
\text { Leu gene }\end{array}$ & $\begin{array}{l}\text { Multiple OXPHOS } \\
\text { defects }\end{array}$ & $\begin{array}{l}\text { Discontinuous circumferential } \\
\text { perifoveal atrophy with sparing } \\
\text { of the fovea } \\
\text { Alternatively, a pattern dystrophy } \\
\text { characterized by RPE changes } \\
\text { surrounding vascular arcades } \\
\text { with relative sparing of the fovea }\end{array}$ & No & Yes \\
\hline $\begin{array}{l}\text { Chronic } \\
\text { progressive external } \\
\text { ophthalmoplegia }\end{array}$ & $\begin{array}{l}\text { Large-scale } \\
\text { rearrangements of } \\
\text { mtDNA } \\
\text { Maternal inherited } \\
\text { CPEO: point } \\
\text { mutations in } \\
\text { mitochondrial } \\
\text { tRNA genes }\end{array}$ & $\begin{array}{l}\text { Multiple OXPHOS } \\
\text { defects }\end{array}$ & $\begin{array}{l}\text { Bilateral ptosis, ophthalmoplegia } \\
\text { Progressive fibrosis of } \\
\text { extraocular muscles } \\
\text { Pigmentary retinopathy, optic } \\
\text { neuropathy, corneal opacity, } \\
\text { cataracts may occur also }\end{array}$ & Yes & Yes \\
\hline $\begin{array}{l}\text { Kearns-Sayre } \\
\text { syndrome }\end{array}$ & $\begin{array}{l}\text { Large-scale } \\
\text { rearrangements } \\
\text { of mtDNA }\end{array}$ & $\begin{array}{l}\text { Multiple OXPHOS } \\
\text { defects }\end{array}$ & $\begin{array}{l}\text { Severe subtype of CPEO, } \\
\text { with ptosis, ophthalmoplegia, } \\
\text { and pigmentary retinopathy, } \\
\text { plus specific extraocular } \\
\text { systemic criteria }\end{array}$ & Yes & Yes \\
\hline Friedreich's ataxia & $\begin{array}{l}\text { GAA trinucleotide } \\
\text { repeat expansion } \\
\text { in the frataxin gene }\end{array}$ & $\begin{array}{l}\text { Impairment of iron-sulfur } \\
\text { containing mitochondrial } \\
\text { proteins including } \\
\text { OXPHOS } \\
\text { complex I, II, and III }\end{array}$ & $\begin{array}{l}\text { Optic atrophy and degeneration } \\
\text { of optic radiations } \\
\text { Slowly progressive or } \\
\text { occasionally LHON-like } \\
\text { subacute optic neuropathy }\end{array}$ & Yes & No \\
\hline $\begin{array}{l}\text { Mohr-Tranebjaerg } \\
\text { syndrome }\end{array}$ & $\begin{array}{l}\text { Deafness/dystonia } \\
\text { peptide DDPI/ } \\
\text { TIMM8A }\end{array}$ & $\begin{array}{l}\text { Mitochondrial protein } \\
\text { import, secondary } \\
\text { OXPHOS defects }\end{array}$ & $\begin{array}{l}\text { Visual dysfunctions from loss } \\
\text { of the visual cortex, optic } \\
\text { atrophy and degeneration } \\
\text { of retinal inner nuclear layer }\end{array}$ & Yes & No \\
\hline $\begin{array}{l}\text { Hereditary spastic } \\
\text { paraplegia }\end{array}$ & $\begin{array}{l}\text { Mutations in } \\
\text { numerous nuclear } \\
\text { genes, for example } \\
\text { SPG7 (paraplegin) }\end{array}$ & $\begin{array}{l}\text { Impairment of } \\
\text { OXPHOS complex I }\end{array}$ & $\begin{array}{l}\text { Pathological descriptions } \\
\text { of the optic nerve have not } \\
\text { been reported }\end{array}$ & Yes & No \\
\hline $\begin{array}{l}\text { Charcot-Marie- } \\
\text { Tooth disease } \\
\text { subtype CMT2A }\end{array}$ & Mfn2 & $\begin{array}{l}\text { Mitochondrial outer } \\
\text { membrane fusion defects }\end{array}$ & $\begin{array}{l}\text { Subacute onset of optic } \\
\text { atrophy and subsequent slow } \\
\text { recovery of visual acuity }\end{array}$ & Yes & No \\
\hline
\end{tabular}

Abbreviations: OXPHOS, oxidative phosphorylation; CPEO, chronic progressive external ophthalmoplegia; LHON, Leber's hereditary optic neuropathy. 
Two major risk factors are aging and increased intraocular pressure. ${ }^{123,124}$ Around $30 \%-40 \%$ of patients do not present with intraocular pressures above population means, indicating that glaucoma is a complex disease, and age-related mitochondrial failure has been hypothesized to play a role. ${ }^{125-127}$

Despite some clinical similarities, the pattern of retinal ganglion cell loss is considerably different in glaucoma to that seen in LHON and ADOA. In the latter diseases, the small fibers of the papillomacular bundle are preferentially affected, resulting in temporal atrophy and central vision loss. In primary open angle glaucoma, peripapillary atrophy classically leads to an arcuate, peripheral vision loss. However, this cannot be taken as evidence for a lack of oxidative phosphorylation involvement in some patients with glaucoma. As noted earlier for the nonsyndromic mitochondrial optic neuropathies, different patterns of optic nerve, retinal, and wider visual system pathology can result from mitochondrial dysfunction.

\section{Age-related macular degeneration}

Age-related macular degeneration is a late-onset neurodegenerative disease that shares several clinical and biological features associated with Alzheimer's disease. In most cases, age-related macular degeneration involves the buildup of protein plaques, known as drusen, in the central macular region of the retina. Stress stimuli including oxidative stress, aging, genetic factors, and inflammation may drive both age-related macular degeneration and Alzheimer's disease pathogenesis, ${ }^{128}$ including the depositing of protein plaques in the retina or brain. Similarities in these two diseases are also seen with polymorphisms in the risk factor gene, $A P O E$, being associated with age-related macular degeneration, ${ }^{129,130}$ as well as Alzheimer's disease. ${ }^{131,132}$ The APOE gene regulates the homeostasis of triglycerides and cholesterol, ${ }^{133}$ and loss of function of $A P O E$ has been linked to the deposit of senile plaques, mainly comprised of the amyloid beta peptide, ${ }^{134}$ which build up in drusen $^{135,136}$ and also colocalize with another risk factor for age-related macular degeneration, ie, complement protein. ${ }^{137,138}$ Evidence indicates the genotype of APOE may dictate the risk of Alzheimer's disease and other chronic disorders, largely due to its impact on oxidative stress modulation. ${ }^{139}$

Age-related macular degeneration is divided into two major forms, ie, the "wet" form caused by leakage from choroidal neovascularization into the subretinal space, and the more common "dry" form associated with buildup of drusen in the macula. ${ }^{140}$ There is an increased prevalence of large-scale mtDNA rearrangements and deletions in both the blood $^{141}$ and retinas ${ }^{142,143}$ of patients with age-related macular degeneration. There are also increased rates of single nucleotide polymorphisms in the noncoding mtDNA control region (d-loop) in retinas with age-related macular degeneration, ${ }^{30}$ which has been observed in Alzheimer's disease and other oxidative stress conditions. ${ }^{144}$ It is likely that an increased rate of mtDNA deletions and single nucleotide polymorphisms diminishes the number and density of mitochondria, which may partially explain the decreased mitochondrial density observed in age-related macular degeneration retinas. ${ }^{145}$ The various components affecting mitochondrial function and the dynamics and mechanisms by which they contribute to mitochondrial disorders of the eye are summarized in Figure 1.

\section{Diagnostic approaches}

In some cases, a clinical phenotype can be a strong predictor of the underlying molecular features. In both LHON and ADOA, evaluation of history, optic nerve head morphology, and optic nerve function can be predictive of disease. ${ }^{146}$ However, both ADOA and LHON may be misdiagnosed as glaucoma on optic nerve head examination alone, and training programs may aid in accurate diagnosis of glaucoma ${ }^{147}$ and other optic neuropathies. ${ }^{148}$ When a mutation is suspected in retinal degenerative conditions, several considerations for patient counseling must be investigated. These include a positive family history of disease, typical clinical ophthalmic features for known mitochondrial diseases (including retinal and optic disc appearance, and optic nerve head appearance), ${ }^{148}$ and laboratory investigations ${ }^{149,150}$ which all aid identification of genetic involvement.

The complexity of mitochondrial disorders is enhanced by the dual genetic coding of mitochondrial oxidative phosphorylation from both nDNA and mtDNA. The mode of inheritance of mitochondrial disease can be maternal, autosomal dominant, autosomal recessive, or X-linked, which complicates genetic counseling for suspected patients and families. ${ }^{151}$ Mitochondrial DNA mutations, either heritable or acquired through aging and as a consequence of oxidative stress, may underlie retinal ganglion cell loss. Identifying the type of mtDNA mutation is challenging, because mutations may be either heritable at known positions (eg, in LHON) or due to single nucleotide polymorphisms, point mutations, or large-scale deletions and rearrangements. Diagnosis of mtDNA mutation also faces the challenge that different tissues may harbor different levels of mutant and wild-type mtDNA (heteroplasmy). ${ }^{21}$ In LHON patients, varying levels of heteroplasmy of mutant mtDNA were identified between hair follicles and blood cells, ${ }^{152}$ and a LHON patient had higher levels of mutant mtDNA in their retina and optic nerves than in their blood cells at post mortem. ${ }^{153}$ In age-related 


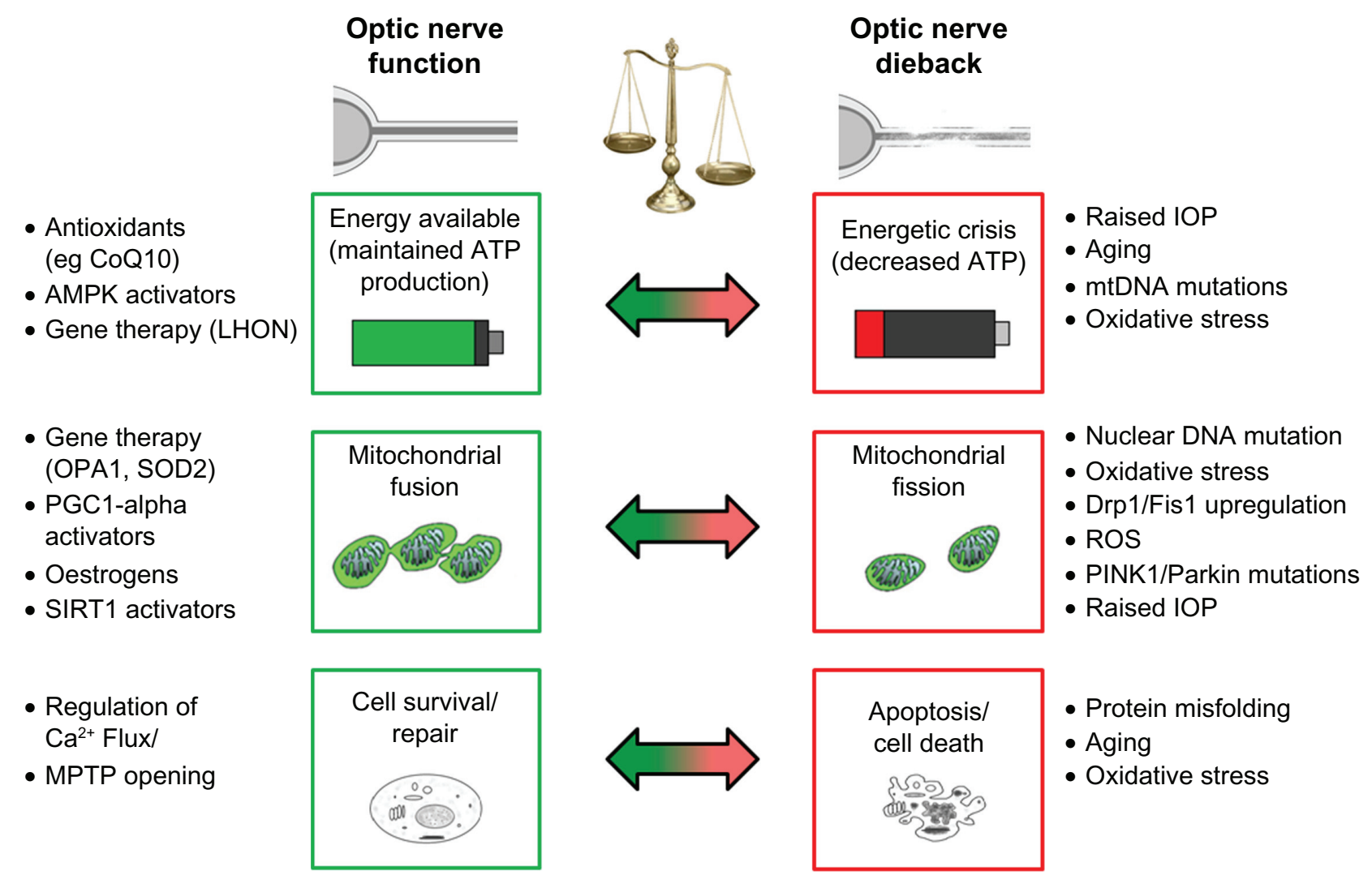

Figure I Factors contributing to optic nerve degeneration.

Note: The spectrum of mitochondrial dysfunction in the eye has emerged through understanding of the contribution of multiple stressors leading to mitochondrial failure and optic nerve loss. While controversy continues as to whether mitochondrial impairment in these diseases is primary or secondary to upstream disease pathways, the mitochondrion is emerging as a central culprit in cell death.Therapeutic developments aimed at boosting mitochondrial function are gathering pace. These approaches are likely to be of benefit not only in retinal disease, but also in diseases of the aging brain due to the growing evidence for a role of mitochondrial decline in age-related neurodegeneration.

macular degeneration, post mortem analysis of retinas and peripheral blood demonstrated a greater accumulation of rearrangements and deletions of mtDNA in retinas. ${ }^{141}$

Aside from genetic screening, functional laboratory investigations may give clues to the underlying pathogenesis of the mitochondrial disease. Typical laboratory investigations require sampling of biopsy tissue (eg, leucocytes, muscle, fibroblasts) for functional mitochondria studies. ${ }^{149,150}$ Detailed oxidative phosphorylation enzymatic studies may be undertaken from the tissue or cell line, but technique standardization is require $\mathrm{d}^{149,154}$ due to interlaboratory variation in methods. ${ }^{155}$ Mitochondrial function can also be determined noninvasively. Phosphorus magnetic resonance spectroscopy is well suited to gathering clinical data on skeletal muscle energetics, and is a very sensitive index of mitochondrial function which has been used to study bioenergetic defects in ADOA and LHON. ${ }^{3,81,156-158}$

Coupled with a positive clinical appearance, a better molecular understanding of the mitochondrial involvement in conditions of the eye will guide therapeutic development. We believe the future holds several avenues of therapeutic potential to ameliorate mitochondrial dysfunction, which are outlined below.

\section{Avenues for neuroprotection Gene therapy in the eye}

Since the retina and optic nerve are part of the central nervous system, yet are relatively accessible, this provides an attractive opportunity to study the regenerative responses of adult neuronal cells to gene therapy. Current means of gene delivery may be via the use of replication-deficient viral vectors, recombinant plasmids, or electroporation. Gene replacement of defective genes (eg, LHON complex I), the therapeutic use of antioxidant genes (eg, superoxide dismutase, SOD) and increasing expression of haploinsufficient proteins (eg, OPA1 in ADOA) are currently under investigation. These may also hold promise in the treatment of other degenerative conditions, including glaucoma and optic neuritis. Haploinsufficiency of the OPA1 protein is the underlying pathogenic mechanism of retinal ganglion cell loss in human ADOA patients, ${ }^{78}$ and OPA1 haploinsufficiency negatively affects retinal ganglion cell survival and function in animal models. ${ }^{159-161}$ 
Increasing OPA1 expression is being investigated as a means to ameliorate retinal ganglion cell loss. In cultured cells, the protective effect of increased OPA1 expression prevented cells undergoing apoptosis ${ }^{82,162}$ and protected against excitotoxicity. ${ }^{163}$ Adenovirus-associated virus vector (AAV2) transfection of OPA1 into glaucomatous DBA/2 J mouse retinas protected against loss of retinal ganglion cells, with protection persisting up to two months after transfection. ${ }^{71}$

Retinal ganglion cells are under constant oxidative stress, and boosting antioxidant defenses or providing neurotrophic factors may support retinal ganglion cell survival. Cells with the G1178A LHON mutation suffer increased oxidative stress levels. ${ }^{77}$ AAV-mediated delivery of mitochondrial SOD (SOD2) improved cell survival when cells were cultured in galactose media where cells are forced to rely on oxidative phosphorylation for all ATP production. ${ }^{164}$ When the SOD2 concept was transferred into an animal model with severe complex I defects in the retina induced by ribozyme-mediated knockdown of a nuclear complex I gene, the same group demonstrated protection of optic nerve fibers by preventing early apoptosis of retinal ganglion cells. ${ }^{165}$ There have also been extensive animal trials on the AAV-mediated delivery of trophic factors (eg, ciliary neurotrophic factor) in promoting retinal ganglion cell growth and axonal regeneration in optic nerve transection or optic nerve crush models. ${ }^{166}$

The ability to reverse, correct, or replace an inherited genetic mutation is a potential strength of gene therapy. Homologous recombination has not been convincingly demonstrated to occur in mtDNA, which has prevented the correction of heritable mtDNA mutations. ${ }^{167-170}$ This has also challenged modeling of mtDNA diseases in rodents and has required alternate approaches. LHON-like phenotypes were induced either by the intravitreal injection of rotenone, a toxic complex I inhibitor, ${ }^{171-173}$ or by delivery of mutant human ND subunits into the retina by either electroporation ${ }^{174}$ or AAV-mediated delivery. ${ }^{164}$

Various groups are now exploring the concept of replacing mutant complex I genes by allotropic rescue in animal models. ${ }^{172,174,175}$ This concept involves the introduction of recoded human mtDNA genes, with an added mitochondrial import presequence into the nuclear genome of rodents by AAV delivery. However, these experiments face the uncertainty of whether introducing human mitochondrial genes into rodent cells would result in functional improvement of oxidative phosphorylation. Mismatching of nuclear and mitochondrial encoded oxidative phosphorylation subunits in cybrid models takes advantage of evolutionary divergence, which is sufficient to cause mitochondrial dysfunction. ${ }^{176-178}$
Thus, the successful delivery of human ND4 subunits into the mitochondrion does not necessarily provide a functional benefit to the murine mitochondria, nor does it guarantee correct assembly into functional oxidative phosphorylation complexes. These findings have also raised questions on whether AAV delivery of highly hydrophobic complex I subunits would be correctly assembled into mitochondrial membranes in vivo. ${ }^{3,179-181}$

Although some of these results appear promising, much caution needs to be in place before commencing human trials because there are a number of concerns relating to the safety of gene rescue. ${ }^{179,182}$ To date, no human trials have commenced with AAV-mediated gene delivery into the retina, although patient selection and recruitment is actively taking place for LHON gene therapy trials, and a cohort of patients has already been identified and selected for suitability of inclusion in these trials. ${ }^{183}$

\section{Regulation of hormonal agents}

Phenylbutyrate is a histone deacetylase inhibitor currently being used as a treatment in Parkinson's disease due to its neuroprotective properties against oxidative cell death. ${ }^{184-187}$ The action of phenylbutyrate is mediated partly via activation of the protein $\mathrm{DJ} 1$, which was protective against mouse models of neurodegeneration induced by treatment with the oxidative phosphorylation complex I inhibitors rotenone or 1-methyl-4-phenyl-1,2,3,6-tetrahydropyridine. ${ }^{187,188}$ Phenylbutyrate treatment prior to ischemic intraocular pressure elevation $(>100 \mathrm{mmHg})$ in the rat retina also protected against retinal ganglion cell loss and preserved retinal thickness. ${ }^{189}$ The activation of DJ1 by phenylbutyrate stabilized nuclear factor erythroid 2-related factor, a master regulator of antioxidant transcription response, ${ }^{190}$ as well as working in parallel with the pink/PARKIN pathway to protect mitochondrial function in the presence of oxidative stress. ${ }^{191,192}$

In response to histone deacetylase inhibition, estrogen receptor alpha $(\mathrm{ER} \alpha)$ is activated and the DNA binding capacity of ER $\alpha$ is increased. ${ }^{193}$ Deacetylation of ER $\alpha$ is also regulated by histone deacetylator 8 and sirtuin 1 homolog, which act together as independent enhancers of ER $\alpha$ activity. ${ }^{193}$ Mitochondrial biogenesis involves signaling via numerous transcription factors and transcriptional coactivators, one being estrogen-related receptor (ERR) $8 \alpha$, that works in concert with the peroxisome proliferator-activated receptor gamma (PPAR $\gamma$ ) coactivator (PGC1 $\alpha$ ) family. ${ }^{194}$ Estrogen receptor signalling may be a means to activate mitochondrial transcription ${ }^{195,196}$ via estradiol treatment, ${ }^{197}$ which upregulates 
mtDNA-encoded complex IV genes. ${ }^{198,199}$ Estrogens may have a vital role in maintaining mitochondrial function during stress, and have been shown to ameliorate the LHON complex I defect by enhancing mitochondrial biogenesis and improving mitochondrial energy production. ${ }^{200}$ The putative antioxidant role of estrogens has also been supported by evidence from cybrid cell lines of LHON treated with $17 \beta$-estradiol, which demonstrated increased antioxidant SOD, stabilization of the mitochondrial membrane potential, ${ }^{201}$ and more efficient mitochondrial biogenesis. ${ }^{3}$ Estrogens also contribute to the regulation of glucose metabolism and insulin sensitivity via activation of $E R \alpha .^{202,203}$ The effect of estrogens on pathways regulating cellular energy levels has been demonstrated by the ability of $17 \beta$-estradiol to phosphorylate and activate AMP-activated protein kinase (AMPK), the master initiator of cellular catabolism, independently of AMP level. ${ }^{204}$

As such, estrogens and novel nonhormonal analogs are of interest to protect neurons against acute brain injury and chronic neurodegeneration, ${ }^{205}$ and the evidence suggests a protective mechanism against increased intraocular pressure in rodents. ${ }^{206}$ There is also evidence that estrogen therapy (with estradiol) was able to increase retinal blood flow in rodent models, ${ }^{207}$ as well as improving optic nerve head topography and optic nerve head blood flow in postmenopausal women on hormone replacement therapy, ${ }^{207}$ which may protect the retina against injury. $17 \beta$-estradiol treatment also conferred neuroprotection in hippocampal neurons exposed to glutamate excitotoxicity by regulation of mitochondrial calcium load. ${ }^{208}$

\section{Regulation of mitochondrial biogenesis as a therapeutic target}

The preservation of healthy mitochondrial function in neurodegeneration has guided emerging mitochondrial therapies towards examining mitochondrial biogenesis as a therapeutic target. Several reviews have highlighted the mechanisms of mitochondrial biogenesis and its role in neuroprotection. ${ }^{209-212}$

One master transcriptional regulator of mitochondrial biogenesis is PPAR $\gamma$ coactivator $(\mathrm{PGC} 1 \alpha){ }^{213} \mathrm{PGC} 1 \alpha$ regulates mitochondrial homeostasis through upregulation of mitochondrial biogenesis, respiration, and controlling the utilization of substrates for energy production. ${ }^{214}$

The PPARs are ligand-controlled upstream regulators of PGC1 $\alpha$ activity involved in transcription of genes responsible for fatty acid transport and mitochondrial oxidation. Synthetic PPAR agonists have been developed for the management of type 2 diabetes (PPAR $\gamma$ agonists, eg, thiazolidediones), and lipid disorders (PPAR $\alpha$ agonists, eg, fibrates). The thiazolidedione class of medications has demonstrated a neuroprotective effect of two PPAR $\gamma$ ligands (troglitazone and 15d-PGJ2) in glutamate-induced cytotoxicity in a rat neuronal precursor cell culture model. ${ }^{215}$ PPAR $\gamma$ agonists also demonstrated a role in neurorecovery following transient ischemic injury. ${ }^{216-218}$

Given the high energy demand yet poor nutrient storage capability of central nervous system neurons, ${ }^{219}$ it is not surprising that regulation of cellular energy is pivotal in the context of mitochondrial dysfunction in disorders of aging and the eye. AMPK is an evolutionary preserved cellular "calorimeter" common to all eukaryotes that acts as a cellular switch to activate catabolic pathways and turns off anabolic pathways. ${ }^{20,221}$ AMPK is intimately related to mitochondrial oxidative phosphorylation because the energy-sensing process is sensitive to changes in the ratio of cellular AMP to ATP. ${ }^{22}$ Low ATP levels activate AMPK by phosphorylation of AMPK at Thr172 in the kinase domain, ${ }^{223}$ and AMPK is implicated in promoting mitochondrial biogenesis through PGC1 $\alpha$. The glitazone class of medication has been shown to phosphorylate and thereby activate AMPK in muscle by increasing the AMP:ATP ratio. ${ }^{224}$ Activated nuclear AMPK complexes are able to phosphorylate mitochondrial transcriptional coregulators directly, including PGC1 $\alpha .^{225}$ The potential for pharmacological activation of AMPK in promoting mitochondrial biogenesis and conferring neuroprotection has been suggested by in vitro studies using metformin, a biguanide commonly used in the management of type 2 diabetes. ${ }^{226,227}$ This highlights several mechanisms by which regulation of $\mathrm{PGC} 1 \alpha$ can exert neuroprotection in the central nervous system.

The silent information regulator T1 (SIRT1) is also influential in mitochondrial function, biogenesis, and neuroprotection. SIRT1 is an enzyme that belongs to the sirtuin gene family. It acts as a metabolic sensor and mediates the regulation of oxidation and energy homeostasis genes through $\mathrm{NAD}^{+}$-dependent deacetylation of transcription factors. ${ }^{214}$ Independent of deacetylase activity, sirtuins have been implicated in mitochondrial function through antioxidant properties ${ }^{228}$ and regulation of oxidative stress genes. ${ }^{229}$ Furthermore, SIRT1 activation deacetylates PGC1 $\alpha$, thereby activating mitochondrial biogenesis. ${ }^{230}$ SIRT1 has also demonstrated immunomodulatory neuroprotection of retinal ganglion cells in models of autoimmune optic neuritis. $^{231}$ These mechanisms of SIRT1 activation have therefore set the foundation for potential neuroprotective interventions. 
Calorie restriction is one such established method of improving mitochondrial biogenesis, ${ }^{232}$ respiration, ${ }^{233}$ and reduction of reactive oxygen species production through upregulation of SIRT $1 .{ }^{234}$ Calorie restriction has been shown to facilitate retinal ganglion cell recovery in acute intraocular pressure challenge and ischemia-reperfusion models. ${ }^{235}$ Glucose restriction has been shown to activate AMPK, which then activated the gene for the NAD synthetic enzyme, Nampt. ${ }^{236}$ This highlighted an important convergence between AMPK and SIRT1 in mitochondrial biogenesis (Figure 2). ${ }^{237}$ Similarly, resveratrol, a plant polyphenol, mimics the effects of calorie restriction, primarily through activation of SIRT1, but also activation of AMPK in several tissues. ${ }^{238,239}$ It has demonstrated neuroprotective effects in acute and chronic central nervous system injury. ${ }^{53,240,241}$ Additionally, the antioxidant properties of resveratrol were shown to reduce the production of reactive oxygen species and inflammatory markers in the trabecular meshwork in primary open angle glaucoma, ${ }^{242}$ and to protect against hydrogen peroxide-induced retinal pigment epithelial cell dysfunction that occurs with age-related macular degeneration. ${ }^{243}$

\section{Antioxidant and reactive oxygen species scavenging}

Oxidative stress is a common feature of mitochondrial disease, and evidence points toward a pathogenic involvement in diseases of the eye, as discussed above. Ameliorating oxidative stress may be a potential therapeutic avenue to explore to protect the eye against the adverse effects of aging and mitochondrial dysfunction. There is evidence clinically that antioxidant and vitamin supplementing may benefit mitochondrial diseases, with most promise in the use of coenzyme $\mathrm{Q}_{10}$ and its derivatives, eg, idebenone. The rationale behind their use is to replace naturally depleted stores, to bypass defective electron transfer, and these agents also have naturally occurring antioxidant properties. ${ }^{244}$ In the body, their use may lead to lowering of

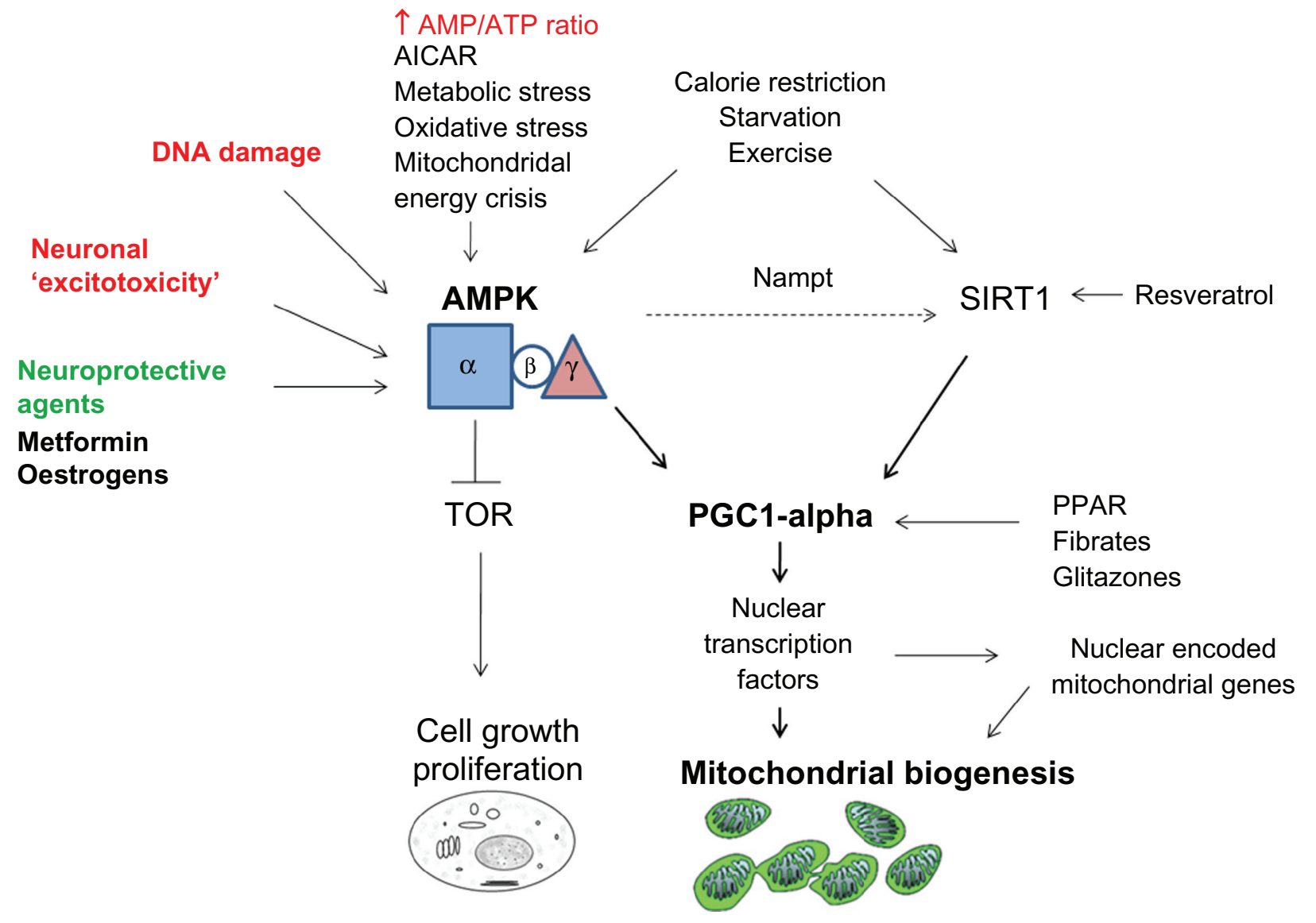

Figure 2 Role of AMPK in neuroprotection.

Note: AMP-Activated protein kinase (AMPK) is a heterotrimic enzyme that activates catabolic pathways and turns off anabolic pathways in response to increased AMP/ATP ratio (hypoxia,glucose deprivation, OXPHOS inhibition), $\mathrm{Ca}^{2+}$ mediated neuronal excitotoxicity, DNA damage. Low ATP levels activate AMPK by phosphorylation of AMPK at ThrI72 in the kinase domain (in the alpha subunit). Once activated, AMPK inhibits ATP consumption, inhibits protein synthesis (by inhibiting Target of Rapamycin, TOR), and inhibits fatty acid and cholesterol synthesis. AMPK can drive mitochondrial biogenesis by phosphorylation of mitochondrial transcriptional coregulators including PGC-I a; and indirectly promote SIRTI activity via regeneration of NAD through the enzyme Nampt. Emerging neuroprotective avenues for AMPK activation act via increasing AMPIATP ratio (Glitazones), Metformin, and Estradiol. 
plasma lactate levels and reducing oxidative stress. ${ }^{245}$ The use of coenzyme $\mathrm{Q}_{10}$ and derivatives is being investigated in children with various mitochondrial disorders ${ }^{246}$ as well as more specifically in patients suffering MELAS ${ }^{247}$ and Parkinson's disease. ${ }^{248}$ Idebenone, a short-chain derivative of coenzyme $\mathrm{Q}_{10}$, has been used to slow the progression of Friedreich's ataxia, ${ }^{249,250}$ and in conjunction with vitamin B2 and vitamin $\mathrm{C}$ to treat LHON. In a clinical trial of $28 \mathrm{LHON}$ patients (14 placebo, 14 treatment), idebenone treatment has been demonstrated to speed the visual recovery period in LHON from 34 months to 17 months $^{251}$ and has proved effective in improving vision in an isolated patient case ${ }^{252}$ but not in two other patients. ${ }^{253}$ Another large Phase II clinical trial involving up to 84 patients to test the effectiveness of idebenone in LHON is underway where an improvement in mean visual acuity is the primary outcome. ${ }^{254} \mathrm{~A}$ trial of idebenone in reducing vision loss in ADOA reported potential benefits in some patients, where five out of seven patients experienced improvement in vision. ${ }^{255}$ These data support the use of idebenone in the treatment of primary mitochondrial optic neuropathies, and may provide potential as a therapeutic in glaucoma and other mitochondrial optic neuropathies.

\section{Conclusion}

The most common ophthalmic manifestation of primary mitochondrial disease is optic atrophy, followed by pigmentary retinopathy and ophthalmoplegia. The majority of mitochondrial disease patients will have variable central nervous system involvement, with ataxias, sensorineural deafness, and peripheral neuropathies being among the most frequently encountered signs. A growing appreciation for the potential role of age-related mitochondrial dysfunction has focused increasing attention on the possible role of mitochondria in the common age-related retinal diseases, age-related macular degeneration and glaucoma. Therapeutic developments aimed at boosting mitochondrial function are gathering pace.

The retina is both a key target of mitochondrial pathology and an ideal model system to test neuroprotective and neuroregenerative therapies. It is likely that advances in retinal neuroprotection via modulation of mitochondrial function will have implications for age-related neurodegenerative brain diseases.

\section{Disclosure}

The authors report no conflicts of interest in this work.

\section{References}

1. Wallace DC, Singh G, Lott MT, et al. Mitochondrial DNA mutation associated with Leber's hereditary optic neuropathy. Science. 1988; 242(4884):1427-1430.
2. Carelli V, La Morgia C, Valentino ML, Barboni P, Ross-Cisneros FN, Sadun AA. Retinal ganglion cell neurodegeneration in mitochondrial inherited disorders. Biochim Biophys Acta. 2009;1787(5): 518-528.

3. Yu-Wai-Man P, Griffiths PG, Chinnery PF. Mitochondrial optic neuropathies - disease mechanisms and therapeutic strategies. Prog Retin Eye Res. 2011;30(2):81-114.

4. Fraser JA, Biousse V, Newman NJ. The neuro-ophthalmology of mitochondrial disease. Surv Ophthalmol. 2010;55(4):299-334.

5. Crouch PJ, Cimdins K, Duce JA, Bush AI, Trounce IA. Mitochondria in aging and Alzheimer's disease. Rejuvenation Res. 2007;10(3): 349-357.

6. Schapira AH, Gegg M. Mitochondrial contribution to Parkinson's disease pathogenesis. Parkinsons Dis. 2011;2011:159-160.

7. Kong GY, Van Bergen NJ, Trounce IA, Crowston JG. Mitochondrial dysfunction and glaucoma. J Glaucoma. 2009;18(2):93-100.

8. Jarrett SG, Lewin AS, Boulton ME. The importance of mitochondria in age-related and inherited eye disorders. Ophthalmic Res. 2010;44(3): 179-190.

9. Wallace DC. Mitochondrial DNA mutations in disease and aging. Environ Mol Mutagen. 2010;51(5):440-450.

10. Wong-Riley M. Energy metabolism of the visual system. Eye and Brain. 2010;2:99-116.

11. Cheng A, Hou Y, Mattson MP. Mitochondria and neuroplasticity. ASN Neuro. 2010;2(5):e00045.

12. Saraste M. Oxidative phosphorylation at the fin de siecle. Science. 1999;283(5407):1488-1493.

13. Clayton DA. Transcription and replication of mitochondrial DNA. Hum Reprod. 2000;15 Suppl 2:11-17.

14. Wallace DC, Fan W, Procaccio V. Mitochondrial energetics and therapeutics. Annu Rev Pathol. 2010;5:297-348.

15. Cadenas E, Boveris A, Ragan CI, Stoppani AO. Production of superoxide radicals and hydrogen peroxide by NADH-ubiquinone reductase and ubiquinol-cytochrome c reductase from beef-heart mitochondria. Arch Biochem Biophys. 1977;180(2):248-257.

16. Turrens JF, Boveris A. Generation of superoxide anion by the NADH dehydrogenase of bovine heart mitochondria. Biochem J. 1980;191(2): 421-427.

17. Wei YH, Lu CY, Lee HC, Pang CY, MaYS. Oxidative damage and mutation to mitochondrial DNA and age-dependent decline of mitochondrial respiratory function. Ann N Y Acad Sci. 1998;854:155-170.

18. Richter C, Park JW, Ames BN. Normal oxidative damage to mitochondrial and nuclear DNA is extensive. Proc Natl Acad Sci USA. 1988;85(17):6465-6467.

19. Clayton DA, Doda JN, Friedberg EC. The absence of a pyrimidine dimer repair mechanism in mammalian mitochondria. Proc Natl Acad Sci U S A. 1974;71(7):2777-2781.

20. Croteau DL, Stierum RH, Bohr VA. Mitochondrial DNA repair pathways. Mutat Res. 1999;434(3):137-148.

21. DiMauro S, Schon EA. Mitochondrial respiratory-chain diseases. N Engl J Med. 2003;348(26):2656-2668.

22. McKenzie M, Liolitsa D, Hanna MG. Mitochondrial disease: mutations and mechanisms. Neurochem Res. 2004;29(3):589-600.

23. St John JC, Facucho-Oliveira J, Jiang Y, Kelly R, Salah R. Mitochondrial DNA transmission, replication and inheritance: a journey from the gamete through the embryo and into offspring and embryonic stem cells. Hum Reprod Update. 2010;16(5):488-509.

24. Hoegger MJ, Lieven CJ, Levin LA. Differential production of superoxide by neuronal mitochondria. BMC Neurosci. 2008;9:4.

25. Cann RL. Genetic clues to dispersal in human populations: retracing the past from the present. Science. 2001;291(5509):1742-1748.

26. Yu-Wai-Man P, Griffiths PG, Hudson G, Chinnery PF. Inherited mitochondrial optic neuropathies. J Med Genet. 2009;46(3):145-158.

27. Abu-Amero KK, Cabrera VM, Larruga JM, Osman EA, Gonzalez AM, Al-Obeidan SA. Eurasian and Sub-Saharan African mitochondrial DNA haplogroup influences pseudoexfoliation glaucoma development in Saudi patients. Mol Vis. 2011;17:543-547. 
28. Wolf C, Gramer E, Muller-Myhsok B, Pasutto F, Wissinger B, Weisschuh N. Mitochondrial haplogroup $U$ is associated with a reduced risk to develop exfoliation glaucoma in the German population. $B M C$ Genet. 2010;11:8.

29. Abu-Amero KK, Morales J, Bosley TM, Mohamed GH, Cabrera VM. The role of mitochondrial haplogroups in glaucoma: a study in an Arab population. Mol Vis. 2008;14:518-522.

30. Udar N, Atilano SR, Memarzadeh M, et al. Mitochondrial DNA haplogroups associated with age-related macular degeneration. Invest Ophthalmol Vis Sci. 2009;50(6):2966-2974.

31. SanGiovanni JP, Arking DE, Iyengar SK, et al. Mitochondrial DNA variants of respiratory complex I that uniquely characterize haplogroup T2 are associated with increased risk of age-related macular degeneration. PLoS One. 2009;4(5):e5508.

32. Torroni A, Petrozzi M, D’Urbano L, et al. Haplotype and phylogenetic analyses suggest that one European-specific mtDNA background plays a role in the expression of Leber hereditary optic neuropathy by increasing the penetrance of the primary mutations 11778 and 14484. Am J Hum Genet. 1997;60(5):1107-1121.

33. Yu D, Jia X, Zhang AM, et al. Mitochondrial DNA sequence variation and haplogroup distribution in Chinese patients with LHON and m.14484T>C. PLoS One. 2010;5(10):e13426.

34. Zhang M, Zhou X, Li C, et al. Mitochondrial haplogroup M9a specific variant ND1 T3394C may have a modifying role in the phenotypic expression of the LHON-associated ND4 G11778A mutation. Mol Genet Metab. 2010;101(1-3):192-199.

35. Zhou X, Zhang H, Zhao F, et al. Very high penetrance and occurrence of Leber's hereditary optic neuropathy in a large Han Chinese pedigree carrying the ND4 G11778A mutation. Mol Genet Metab. 2010;100(4): 379-384.

36. Ji Y, Zhang AM, Jia X, et al. Mitochondrial DNA haplogroups M7b1'2 and M8a affect clinical expression of Leber hereditary optic neuropathy in Chinese families with the $\mathrm{m} .11778 \mathrm{G}>$ a mutation. Am J Hum Genet. 2008;83(6):760-768.

37. Carelli V, Achilli A, Valentino ML, et al. Haplogroup effects and recombination of mitochondrial DNA: novel clues from the analysis of Leber hereditary optic neuropathy pedigrees. Am J Hum Genet. 2006; 78(4):564-574.

38. Sudoyo H, Suryadi H, Lertrit P, Pramoonjago P, Lyrawati D, Marzuki S. Asian-specific mtDNA backgrounds associated with the primary G11778 A mutation of Leber's hereditary optic neuropathy. J Hum Genet. 2002;47(11):594-604.

39. Lamminen T, Huoponen K, Sistonen P, et al. mtDNA haplotype analysis in Finnish families with Leber hereditary optic neuroretinopathy. Eur J Hum Genet. 1997;5(5):271-279.

40. Hudson G, Carelli V, Spruijt L, et al. Clinical expression of Leber hereditary optic neuropathy is affected by the mitochondrial DNAhaplogroup background. Am J Hum Genet. 2007;81(2):228-233.

41. Marcuello A, Martinez-Redondo D, Dahmani Y, et al. Human mitochondrial variants influence on oxygen consumption. Mitochondrion. 2009;9(1):27-30.

42. Ghelli A, Porcelli AM, Zanna C, et al. The background of mitochondrial DNA haplogroup J increases the sensitivity of Leber's hereditary optic neuropathy cells to 2,5-hexanedione toxicity. PLoS One. 2009;4(11): e7922.

43. Pello R, Martin MA, Carelli V, et al. Mitochondrial DNA background modulates the assembly kinetics of OXPHOS complexes in a cellular model of mitochondrial disease. Hum Mol Genet. 2008;17(24): 4001-4011.

44. Kacser H, Burns JA. Molecular democracy: who shares the controls? Biochem Soc Trans. 1979;7(5):1149-1160.

45. Andrews RM, Griffiths PG, Johnson MA, Turnbull DM. Histochemical localisation of mitochondrial enzyme activity in human optic nerve and retina. Br J Ophthalmol. 1999;83(2):231-235.

46. Bristow EA, Griffiths PG, Andrews RM, Johnson MA, Turnbull DM. The distribution of mitochondrial activity in relation to optic nerve structure. Arch Ophthalmol. 2002;120(6):791-796.
47. Hollander H, Makarov F, Stefani FH, Stone J. Evidence of constriction of optic nerve axons at the lamina cribrosa in the normotensive eye in humans and other mammals. Ophthalmic Res. 1995;27(5):296-309.

48. Kageyama GH, Wong-Riley MT. The histochemical localization of cytochrome oxidase in the retina and lateral geniculate nucleus of the ferret, cat, and monkey, with particular reference to retinal mosaics and ON/OFF-center visual channels. J Neurosci. 1984;4(10):2445-2459.

49. Minckler DS, Bunt AH, Johanson GW. Orthograde and retrograde axoplasmic transport during acute ocular hypertension in the monkey. Invest Ophthalmol Vis Sci. 1977;16(5):426-441.

50. Mutsaers SE, Carroll WM. Focal accumulation of intra-axonal mitochondria in demyelination of the cat optic nerve. Acta Neuropathol. 1998;96(2):139-143.

51. Balaratnasingam C, Morgan WH, Johnstone V, Cringle SJ, Yu DY. Heterogeneous distribution of axonal cytoskeleton proteins in the human optic nerve. Invest Ophthalmol Vis Sci. 2009;50(6):2824-2838.

52. Attardi G. Role of mitochondrial DNA in human aging. Mitochondrion. 2002;2(1-2):27-37.

53. Inoue H, Jiang XF, Katayama T, Osada S, Umesono K, Namura S. Brain protection by resveratrol and fenofibrate against stroke requires peroxisome proliferator-activated receptor alpha in mice. Neurosci Lett. 2003;352(3):203-206.

54. Chen H, Chan DC. Critical dependence of neurons on mitochondrial dynamics. Curr Opin Cell Biol. 2006;18(4):453-459.

55. Uo T, Dworzak J, Kinoshita C, et al. Drp1 levels constitutively regulate mitochondrial dynamics and cell survival in cortical neurons. Exp Neurol. 2009;218(2):274-285.

56. Kijima K, Numakura C, Izumino H, et al. Mitochondrial GTPase mitofusin 2 mutation in Charcot-Marie-Tooth neuropathy type 2A. Hum Genet. 2005;116(1-2):23-27.

57. Lawson VH, Graham BV, Flanigan KM. Clinical and electrophysiologic features of CMT2A with mutations in the mitofusin 2 gene. Neurology. 2005;65(2):197-204.

58. Zuchner S, De Jonghe P, Jordanova A, et al. Axonal neuropathy with optic atrophy is caused by mutations in mitofusin 2. Ann Neurol. 2006; 59(2):276-281.

59. Wolf C, Gramer E, Muller-Myhsok B, et al. Evaluation of nine candidate genes in patients with normal tension glaucoma: a case control study. BMC Med Genet. 2009;10:91.

60. McQuibban GA, Saurya S, Freeman M. Mitochondrial membrane remodelling regulated by a conserved rhomboid protease. Nature. 2003;423(6939):537-541.

61. Pellegrini L, Scorrano L. A cut short to death: PARL and OPA1 in the regulation of mitochondrial morphology and apoptosis. Cell Death Differ. 2007;14(7):1275-1284.

62. Curran JE, Jowett JB, Abraham LJ, et al. Genetic variation in PARL influences mitochondrial content. Hum Genet. 2010;127(2):183-190.

63. Phasukkijwatana N, Kunhapan B, Stankovich J, et al. Genome-wide linkage scan and association study of PARL to the expression of LHON families in Thailand. Hum Genet. 2010;128(1):39-49.

64. McQuibban GA, Bulman DE. The PARLance of Parkinson disease. Autophagy. 2011;7(7):790-792.

65. Gomes LC, Di Benedetto G, Scorrano L. During autophagy mitochondria elongate, are spared from degradation and sustain cell viability. Nat Cell Biol. 2011;13(5):589-598.

66. Yaffe MP. The machinery of mitochondrial inheritance and behavior. Science. 1999;283(5407):1493-1497.

67. Karbowski M, Arnoult D, Chen H, Chan DC, Smith CL, Youle RJ. Quantitation of mitochondrial dynamics by photolabeling of individual organelles shows that mitochondrial fusion is blocked during the Bax activation phase of apoptosis. $J$ Cell Biol. 2004;164(4):493-499.

68. Chen H, Chan DC. Emerging functions of mammalian mitochondrial fusion and fission. Hum Mol Genet. 2005;14 Spec No 2:R283-R289.

69. Chen Y, McMillan-Ward E, Kong J, Israels SJ, Gibson SB. Mitochondrial electron-transport-chain inhibitors of complexes I and II induce autophagic cell death mediated by reactive oxygen species. J Cell Sci. 2007;120(Pt 23):4155-4166. 
70. Jahani-Asl A, Cheung EC, Neuspiel M, et al. Mitofusin 2 protects cerebellar granule neurons against injury-induced cell death. $J$ Biol Chem. 2007;282(33):23788-23798.

71. Ju WK, Kim KY, Duong-Polk KX, Lindsey JD, Ellisman MH, Weinreb RN. Increased optic atrophy type 1 expression protects retinal ganglion cells in a mouse model of glaucoma. Mol Vis. 2010;16: 1331-1342.

72. Dai Y, Weinreb RN, Kim KY, et al. Inducible nitric oxide synthasemediated alteration of mitochondrial OPA1 expression in ocular hypertensive rats. Invest Ophthalmol Vis Sci. 2011;52(5):2468-2476.

73. Brown MD, Trounce IA, Jun AS, Allen JC, Wallace DC. Functional analysis of lymphoblast and cybrid mitochondria containing the 3460 , 11778 , or 14484 Leber's hereditary optic neuropathy mitochondrial DNA mutation. J Biol Chem. 2000;275(51):39831-39836.

74. Korsten A, de Coo IF, Spruijt L, de Wit LE, Smeets HJ, Sluiter W. Patients with Leber hereditary optic neuropathy fail to compensate impaired oxidative phosphorylation. Biochim Biophys Acta. 2010; 1797(2):197-203.

75. Kjer P. Infantile optic atrophy with dominant mode of inheritance: a clinical and genetic study of 19 Danish families. Acta Ophthalmol Suppl. 1959;164 Suppl 54:1-147.

76. Carelli V, La Morgia C, Iommarini L, et al. Mitochondrial optic neuropathies: how two genomes may kill the same cell type? Biosci Rep. 2007;27(1-3):173-184

77. Carelli V, Ross-Cisneros FN, Sadun AA. Mitochondrial dysfunction as a cause of optic neuropathies. Prog Retin Eye Res. 2004;23(1): 53-89.

78. Marchbank NJ, Craig JE, Leek JP, et al. Deletion of the OPA1 gene in a dominant optic atrophy family: evidence that haploinsufficiency is the cause of disease. J Med Genet. 2002;39(8):e47.

79. Kim JY, Hwang JM, Ko HS, Seong MW, Park BJ, Park SS. Mitochondrial DNA content is decreased in autosomal dominant optic atrophy. Neurology. 2005;64(6):966-972.

80. Amati-Bonneau P, Valentino ML, Reynier P, et al. OPA1 mutations induce mitochondrial DNA instability and optic atrophy 'plus' phenotypes. Brain. 2008;131(Pt 2):338-351.

81. Hudson G, Amati-Bonneau P, Blakely EL, et al. Mutation of OPA1 causes dominant optic atrophy with external ophthalmoplegia, ataxia, deafness and multiple mitochondrial DNA deletions: a novel disorder of mtDNA maintenance. Brain. 2008;131(Pt 2):329-337.

82. Cipolat S, Martins de Brito O, Dal Zilio B, Scorrano L. OPA1 requires mitofusin 1 to promote mitochondrial fusion. Proc Natl Acad Sci USA. 2004;101(45):15927-15932.

83. Frezza C, Cipolat S, Martins de Brito O, et al. OPA1 controls apoptotic cristae remodeling independently from mitochondrial fusion. Cell.2006; 126(1):177-189.

84. Olichon A, Baricault L, Gas N, et al. Loss of OPA1 perturbates the mitochondrial inner membrane structure and integrity, leading to cytochrome c release and apoptosis. J Biol Chem. 2003;278(10):7743-7746.

85. Elachouri G, Vidoni S, Zanna C, et al. OPA1 links human mitochondrial genome maintenance to mtDNA replication and distribution. Genome Res. 2011;21(1):12-20.

86. Van Bergen NJ, Crowston JG, Kearns LS, et al. Mitochondrial oxidative phosphorylation compensation may preserve vision in patients with OPA1-linked autosomal dominant optic atrophy. PLoS One. 2011;6(6):e21347.

87. Mäkelä-Bengs P, Suomalainen A, Majander A. Correlation between the clinical symptoms and the proportion of mitochondrial DNA carrying the 8993 point mutation in the NARP syndrome. Pediatr Res. 1995; 37(5):634-639.

88. Sue CM, Mitchell P, Crimmins DS, Moshegov C, Byrne E, Morris JG. Pigmentary retinopathy associated with the mitochondrial DNA 3243 point mutation. Neurology. 1997;49(4):1013-1017.

89. Van den Ouweland JM, Lemkes HH, Ruitenbeek W, et al. Mutation in mitochondrial tRNA(Leu)(UUR) gene in a large pedigree with maternally transmitted type II diabetes mellitus and deafness. Nat Genet. 1992;1(5):368-371.
90. Reardon W, Ross RJ, Sweeney MG, et al. Diabetes mellitus associated with a pathogenic point mutation in mitochondrial DNA. Lancet. 1992; 340(8832):1376-1379.

91. Michaelides M, Jenkins SA, Bamiou DE, et al. Macular dystrophy associated with the A3243G mitochondrial DNA mutation. Distinct retinal and associated features, disease variability, and characterization of asymptomatic family members. Arch Ophthalmol. 2008;126(3): 320-328.

92. Rath PP, Jenkins S, Michaelides M, et al. Characterisation of the macular dystrophy in patients with the A3243G mitochondrial DNA point mutation with fundus autofluorescence. $\mathrm{Br} J$ Ophthalmol. 2008;92(5):623-629.

93. Massin P, Virally-Monod M, Vialettes B, et al. Prevalence of macular pattern dystrophy in maternally inherited diabetes and deafness. GEDIAM Group. Ophthalmology. 1999;106(9):1821-1827.

94. Zeviani M, Moraes CT, DiMauro S, et al. Deletions of mitochondrial DNA in Kearns-Sayre syndrome. Neurology. 1998;51(6):1525.

95. Nishigaki Y, Tadesse S, Bonilla E, et al. A novel mitochondrial tRNA(Leu(UUR)) mutation in a patient with features of MERRF and Kearns-Sayre syndrome. Neuromuscul Disord. 2003;13(4):334-340.

96. Isashiki Y, Nakagawa M, Ohba N, et al. Retinal manifestations in mitochondrial diseases associated with mitochondrial DNA mutation. Acta Ophthalmol Scand. 1998;76(1):6-13.

97. Carroll WM, Kriss A, Baraitser M, Barrett G, Halliday AM. The incidence and nature of visual pathway involvement in Friedreich's ataxia. A clinical and visual evoked potential study of 22 patients. Brain. 1980;103(2):413-434

98. Fortuna F, Barboni P, Liguori R, et al. Visual system involvement in patients with Friedreich's ataxia. Brain. 2009;132(Pt 1):116-123.

99. Givre SJ, Wall M, Kardon RH. Visual loss and recovery in a patient with Friedreich ataxia. J Neuroophthalmol. 2000;20(4):229-233.

100. Binder J, Hofmann S, Kreisel S, et al. Clinical and molecular findings in a patient with a novel mutation in the deafness-dystonia peptide (DDP1) gene. Brain. 2003;126(Pt 8):1814-1820.

101. Jin H, May M, Tranebjaerg L, et al. A novel X-linked gene, DDP, shows mutations in families with deafness (DFN-1), dystonia, mental deficiency and blindness. Nat Genet. 1996;14(2):177-180.

102. Neupert W, Herrmann JM. Translocation of proteins into mitochondria. Annu Rev Biochem. 2007;76:723-749.

103. Koehler CM, Leuenberger D, Merchant S, Renold A, Junne T, Schatz G. Human deafness dystonia syndrome is a mitochondrial disease. Proc Natl Acad Sci U S A. 1999;96(5):2141-2146.

104. Ponjavic V, Andreasson S, Tranebjaerg L, Lubs HA. Full-field electroretinograms in a family with Mohr-Tranebjaerg syndrome. Acta Ophthalmol Scand. 1996;74(6):632-635.

105. Tranebjaerg L, Jensen PK, Van Ghelue M, et al. Neuronal cell death in the visual cortex is a prominent feature of the $\mathrm{X}$-linked recessive mitochondrial deafness-dystonia syndrome caused by mutations in the TIMM8a gene. Ophthalmic Genet. 2001;22(4):207-223.

106. Casari G, De Fusco M, Ciarmatori S, et al. Spastic paraplegia and OXPHOS impairment caused by mutations in paraplegin, a nuclear-encoded mitochondrial metalloprotease. Cell. 1998;93(6): 973-983.

107. Zuchner S, Mersiyanova IV, Muglia M, et al. Mutations in the mitochondrial GTPase mitofusin 2 cause Charcot-Marie-Tooth neuropathy type 2A. Nat Genet. 2004;36(5):449-451.

108. Zhao C, Vollrath D. mTOR pathway activation in age-related retinal disease. Aging (Albany NY). 2011;3(4):346-347.

109. Howell N, Kubacka I, Xu M, McCullough DA. Leber hereditary optic neuropathy: involvement of the mitochondrial ND1 gene and evidence for an intragenic suppressor mutation. Am J Hum Genet. 1991;48(5): 935-942.

110. Jun AS, Trounce IA, Brown MD, Shoffner JM, Wallace DC. Use of transmitochondrial cybrids to assign a complex I defect to the mitochondrial DNA-encoded NADH dehydrogenase subunit 6 gene mutation at nucleotide pair 14459 that causes Leber hereditary optic neuropathy and dystonia. Mol Cell Biol. 1996;16(3):771-777. 
111. Tarnopolsky MA, Baker SK, Myint T, Maxner CE, Robitaille J, Robinson BH. Clinical variability in maternally inherited Leber hereditary optic neuropathy with the G14459 A mutation. Am J Med Genet A. 2004;124A(4):372-376.

112. Yu-Wai-Man P, Griffiths PG, Gorman GS, et al. Multi-system neurological disease is common in patients with OPA1 mutations. Brain. 2010;133(Pt 3):771-786.

113. Beal MF. Aging, energy, and oxidative stress in neurodegenerative diseases. Ann Neurol. 1995;38(3):357-366.

114. Wallace DC. A mitochondrial paradigm of metabolic and degenerative diseases, aging, and cancer: a dawn for evolutionary medicine. Annu Rev Genet. 2005;39:359-407.

115. Wang AL, Lukas TJ, Yuan M, Neufeld AH. Age-related increase in mitochondrial DNA damage and loss of DNA repair capacity in the neural retina. Neurobiol Aging. 2010;31(11):2002-2010.

116. Kann O, Kovacs R. Mitochondria and neuronal activity. Am J Physiol Cell Physiol. 2007;292(2):C641-C657.

117. Abu-Amero KK, Morales J, Bosley TM. Mitochondrial abnormalities in patients with primary open-angle glaucoma. Invest Ophthalmol Vis Sci. 2006;47(6):2533-2541.

118. Izzotti A, Sacca SC, Longobardi M, Cartiglia C. Mitochondrial damage in the trabecular meshwork of patients with glaucoma. Arch Ophthalmol. 2010;128(6):724-730.

119. Izzotti A, Longobardi M, Cartiglia C, Sacca SC. Mitochondrial damage in the trabecular meshwork occurs only in primary open-angle glaucoma and in pseudoexfoliative glaucoma. PLoS One. 2011;6(1): e14567.

120. Tanwar M, Dada T, Sihota R, Dada R. Mitochondrial DNA analysis in primary congenital glaucoma. Mol Vis. 2010;16:518-533.

121. Abu-Amero KK, Morales J, Osman MN, Bosley TM. Nuclear and mitochondrial analysis of patients with primary angle-closure glaucoma. Invest Ophthalmol Vis Sci. 2007;48(12):5591-5596.

122. Kong YX, Van Bergen N, Trounce IA, et al. Increase in mitochondrial DNA mutations impairs retinal function and renders the retina vulnerable to injury. Aging Cell. 2011;10(4):572-583.

123. Quigley HA, Broman AT. The number of people with glaucoma worldwide in 2010 and 2020. Br J Ophthalmol. 2006;90(3):262-267.

124. Dimitrov PN, Mukesh BN, McCarty CA, Taylor HR. Five-year incidence of bilateral cause-specific visual impairment in the Melbourne Visual Impairment Project. Invest Ophthalmol Vis Sci. 2003;44(12):5075-5081

125. Kong YX, Crowston JG, Vingrys AJ, Trounce IA, Bui VB. Functional changes in the retina during and after acute intraocular pressure elevation in mice. Invest Ophthalmol Vis Sci. 2009;50(12):5732-5740.

126. Osborne NN. Mitochondria: Their role in ganglion cell death and survival in primary open angle glaucoma. Exp Eye Res. 2010;90(6):750-757.

127. Chrysostomou V, Trounce IA, Crowston JG. Mechanisms of retinal ganglion cell injury in aging and glaucoma. Ophthalmic Res. 2010; 44(3):173-178.

128. Kaarniranta K, Salminen A, Haapasalo A, Soininen H, Hiltunen M. Age-related macular degeneration (AMD): Alzheimer's disease in the eye? J Alzheimers Dis. 2011;24(4):615-631.

129. Klaver CC, Kliffen M, van Duijn CM, et al. Genetic association of apolipoprotein $\mathrm{E}$ with age-related macular degeneration. Am J Hum Genet. 1998;63(1):200-206.

130. Baird PN, Guida E, Chu DT, Vu HT, Guymer RH. The epsilon2 and epsilon4 alleles of the apolipoprotein gene are associated with age-related macular degeneration. Invest Ophthalmol Vis Sci. 2004; 45(5):1311-1315.

131. Corder EH, Saunders AM, Strittmatter WJ, et al. Gene dose of apolipoprotein E type 4 allele and the risk of Alzheimer's disease in late onset families. Science. 1993;261(5123):921-923.

132. Ding JD, Lin J, Mace BE, et al. Targeting age-related macular degeneration with Alzheimer's disease based immunotherapies: antiamyloid-beta antibody attenuates pathologies in an age-related macular degeneration mouse model. Vis Res. 2008;48(3):339-345.
133. Mahley RW. Apolipoprotein E: cholesterol transport protein with expanding role in cell biology. Science. 1988;240(4852):622-630.

134. Blennow K, de Leon MJ, Zetterberg H. Alzheimer's disease. Lancet. 2006;368(9533):387-403.

135. Dentchev T, Milam AH, Lee VM, Trojanowski JQ, Dunaief JL. Amyloid-beta is found in drusen from some age-related macular degeneration retinas, but not in drusen from normal retinas. Mol Vis. 2003;9:184-190.

136. Luibl V, Isas JM, Kayed R, Glabe CG, Langen R, Chen J. Drusen deposits associated with aging and age-related macular degeneration contain nonfibrillar amyloid oligomers. J Clin Invest. 2006;116(2): $378-385$.

137. Anderson DH, Talaga KC, Rivest AJ, Barron E, Hageman GS, Johnson LV. Characterization of beta amyloid assemblies in drusen: the deposits associated with aging and age-related macular degeneration. Exp Eye Res. 2004;78(2):243-256.

138. Johnson LV, Leitner WP, Rivest AJ, Staples MK, Radeke MJ, Anderson DH. The Alzheimer's A beta-peptide is deposited at sites of complement activation in pathologic deposits associated with aging and age-related macular degeneration. Proc Natl Acad Sci U SA. 2002; 99(18):11830-11835.

139. Jofre-Monseny L, Minihane AM, Rimbach G. Impact of apoE genotype on oxidative stress, inflammation and disease risk. Mol Nutr Food Res. 2008;52(1):131-145.

140. Gass JD, Agarwal A, Lavina AM, Tawansy KA. Focal inner retinal hemorrhages in patients with drusen: an early sign of occult choroidal neovascularization and chorioretinal anastomosis. Retina. 2003; 23(6):741-751.

141. Kenney MC, Atilano SR, Boyer D, et al. Characterization of retinal and blood mitochondrial DNA from age-related macular degeneration patients. Invest Ophthalmol Vis Sci. 2010;51(8):4289-4297.

142. Karunadharma PP, Nordgaard CL, Olsen TW, Ferrington DA. Mitochondrial DNA damage as a potential mechanism for age-related macular degeneration. Invest Ophthalmol Vis Sci. 2010;51(11):5470-5479.

143. Lin $\mathrm{H}, \mathrm{Xu} \mathrm{H}$, Liang FQ, et al. Mitochondrial DNA damage and repair in retinal pigment epithelium associated with aging and agerelated macular degeneration. Invest Ophthalmol Vis Sci. 2011;52(6): 3521-3529.

144. Coskun PE, Beal MF, Wallace DC. Alzheimer's brains harbor somatic mtDNA control-region mutations that suppress mitochondrial transcription and replication. Proc Natl Acad Sci U SA. 2004;101(29): 10726-10731.

145. Feher J, Kovacs I, Artico M, Cavallotti C, Papale A, Balacco Gabrieli C. Mitochondrial alterations of retinal pigment epithelium in age-related macular degeneration. Neurobiol Aging. 2006;27(7):983-993.

146. O'Neill EC, Mackey DA, Connell PP, Hewitt AW, Danesh-Meyer HV, Crowston JG. The optic nerve head in hereditary optic neuropathies. Nat Rev Neurol. 2009;5(5):277-287.

147. O'Neill EC, Kong YX, Connell PP, et al. Gaze behavior among experts and trainees during optic disc examination: Does how we look affect what we see? Invest Ophthalmol Vis Sci. 2011;52(7): 3976-3983.

148. O'Neill EC, Danesh-Meyer HV, Kong GX, et al. Optic disc evaluation in optic neuropathies: the optic disc assessment project. Ophthalmology. 2011;118(5):964-970.

149. Thorburn DR, Chow CW, Kirby DM. Respiratory chain enzyme analysis in muscle and liver. Mitochondrion. 2004;4(5-6):363-375.

150. Trounce IA, Kim YL, Jun AS, Wallace DC. Assessment of mitochondrial oxidative phosphorylation in patient muscle biopsies, lymphoblasts, and transmitochondrial cell lines. Methods Enzymol. 1996;264:484-509.

151. Kirby DM, Thorburn DR. Approaches to finding the molecular basis of mitochondrial oxidative phosphorylation disorders. Twin Res Hum Genet. 2008;11(4):395-411.

152. Yen MY, Yen TC, Pang CY, Liu JH, Wei YH. Mitochondrial DNA mutation in Leber's hereditary optic neuropathy. Invest Ophthalmol Vis Sci. 1992;33(8):2561-2566. 
153. Howell N, Xu M, Halvorson S, Bodis-Wollner I, Sherman J. A heteroplasmic LHON family: tissue distribution and transmission of the 11778 mutation. Am J Hum Genet. 1994;55(1):203-206.

154. Medja F, Allouche S, Frachon P, et al. Development and implementation of standardized respiratory chain spectrophotometric assays for clinical diagnosis. Mitochondrion. 2009;9(5): 331-339.

155. Gellerich FN, Mayr JA, Reuter S, Sperl W, Zierz S. The problem of interlab variation in methods for mitochondrial disease diagnosis: enzymatic measurement of respiratory chain complexes. Mitochondrion. 2004;4(5-6):427-439.

156. Barbiroli B, Montagna P, Cortelli P, et al. Defective brain and muscle energy metabolism shown by in vivo $31 \mathrm{P}$ magnetic resonance spectroscopy in nonaffected carriers of $11778 \mathrm{mtDNA}$ mutation. Neurology. 1995;45(7):1364-1369.

157. Lodi R, Taylor DJ, Tabrizi SJ, et al. In vivo skeletal muscle mitochondrial function in Leber's hereditary optic neuropathy assessed by 31P magnetic resonance spectroscopy. Ann Neurol. 1997;42(4): 573-579.

158. Chinnery PF, Johnson MA, Wardell TM, et al. The epidemiology of pathogenic mitochondrial DNA mutations. Ann Neurol. 2000;48(2): 188-193.

159. Heiduschka P, Schnichels S, Fuhrmann N, et al. Electrophysiological and histologic assessment of retinal ganglion cell fate in a mouse model for OPA1-associated autosomal dominant optic atrophy. Invest Ophthalmol Vis Sci. 2010;51(3):1424-1431.

160. Shahrestani P, Leung HT, Le PK, et al. Heterozygous mutation of Drosophila Opa1 causes the development of multiple organ abnormalities in an age-dependent and organ-specific manner. PLoS One. 2009;4(8):e6867.

161. White KE, Davies VJ, Hogan VE, et al. OPA1 deficiency associated with increased autophagy in retinal ganglion cells in a murine model of dominant optic atrophy. Invest Ophthalmol Vis Sci. 2009;50(6): $2567-2571$

162. Ishihara N, Fujita Y, Oka T, Mihara K. Regulation of mitochondrial morphology through proteolytic cleavage of OPA1. EMBO J. 2006; 25(13):2966-2977.

163. Jahani-Asl A, Pilon-Larose $\mathrm{K}, \mathrm{Xu} \mathrm{W}$, et al. The mitochondrial inner membrane GTPase, optic atrophy 1 (Opa1), restores mitochondrial morphology and promotes neuronal survival following excitotoxicity. J Biol Chem. 2011;286(6):4772-4782.

164. Qi X, Sun L, Hauswirth WW, Lewin AS, Guy J. Use of mitochondrial antioxidant defenses for rescue of cells with a Leber hereditary optic neuropathy-causing mutation. Arch Ophthalmol. 2007;125(2): 268-272.

165. Qi X, Lewin AS, Sun L, Hauswirth WW, Guy J. SOD2 gene transfer protects against optic neuropathy induced by deficiency of complex I. Ann Neurol. 2004;56(2):182-191.

166. Hellstrom M, Harvey AR. Retinal ganglion cell gene therapy and visual system repair. Curr Gene Ther. 2011;11(2):116-131.

167. Pinkert CA, Trounce IA. Generation of transmitochondrial mice: development of xenomitochondrial mice to model neurodegenerative diseases. Methods Cell Biol. 2007;80:549-569.

168. Tracey I, Dunn JF, Radda GK. A 31P-magnetic resonance spectroscopy and biochemical study of the mo(vbr) mouse: potential model for the mitochondrial encephalomyopathies. Muscle Nerve. 1997;20(11): 1352-1359.

169. Irwin MH, Johnson LW, Pinkert CA. Isolation and microinjection of somatic cell-derived mitochondria and germline heteroplasmy in transmitochondrial mice. Transgenic Res. 1999;8(2):119-123.

170. Collombet JM, Wheeler VC, Vogel F, Coutelle C. Introduction of plasmid DNA into isolated mitochondria by electroporation. A novel approach toward gene correction for mitochondrial disorders. $J$ Biol Chem. 1997;272(8):5342-5347.

171. Zhang X, Jones D, Gonzalez-Lima F. Mouse model of optic neuropathy caused by mitochondrial complex I dysfunction. Neurosci Lett. 2002; 326(2):97-100
172. Marella M, Seo BB, Thomas BB, Matsuno-Yagi A, Yagi T. Successful amelioration of mitochondrial optic neuropathy using the yeast NDI1 gene in a rat animal model. PLoS One. 2010;5(7): e11472.

173. Rojas JC, Gonzales-Lima F. Mitochondrial optic neuropathy: in vivo model of neurodegeneration and neuroprotective strategies. Eye and Brain. 2010;2:21-37.

174. Ellouze S, Augustin S, Bouaita A, et al. Optimized allotopic expression of the human mitochondrial ND4 prevents blindness in a rat model of mitochondrial dysfunction. Am J Hum Genet. 2008;83(3): 373-387.

175. Guy J, Qi X, Koilkonda RD, et al. Efficiency and safety of AAV-mediated gene delivery of the human ND4 complex I subunit in the mouse visual system. Invest Ophthalmol Vis Sci. 2009;50(9): 4205-4214.

176. Pogozelski WK, Fletcher LD, Cassar CA, Dunn DA, Trounce IA, Pinkert CA. The mitochondrial genome sequence of Mus terricolor: comparison with Mus musculus domesticus and implications for xenomitochondrial mouse modeling. Gene. 2008;418(1-2): 27-33.

177. McKenzie M, Trounce I. Expression of Rattus norvegicus mtDNA in Mus musculus cells results in multiple respiratory chain defects. J Biol Chem. 2000;275(40):31514-31519.

178. McKenzie M, Chiotis M, Pinkert CA, Trounce IA. Functional respiratory chain analyses in murid xenomitochondrial cybrids expose coevolutionary constraints of cytochrome $\mathrm{b}$ and nuclear subunits of complex III. Mol Biol Evol. 2003;20(7):1117-1124.

179. Perales-Clemente E, Fernandez-Silva P, Acin-Perez R, Perez-Martos A Enriquez JA. Allotopic expression of mitochondrial-encoded genes in mammals: achieved goal, undemonstrated mechanism or impossible task? Nucleic Acids Res. 2011;39(1):225-234.

180. Koilkonda RD, Guy J. Leber's hereditary optic neuropathy - gene therapy: From benchtop to bedside. J Ophthalmol. 2011;Article ID 179412.

181. Sadun AA, Morgia CL, Carelli V. Leber's hereditary optic neuropathy. Curr Treat Options Neurol. 2011;13(1):109-117.

182. Figueroa-Martinez F, Vazquez-Acevedo M, Cortes-Hernandez $\mathrm{P}$, et al. What limits the allotopic expression of nucleus-encoded mitochondrial genes? The case of the chimeric Cox3 and Atp6 genes. Mitochondrion. 2011;11(1):147-154.

183. Lam BL, Feuer WJ, Abukhalil F, Porciatti V, Hauswirth WW, Guy J. Leber hereditary optic neuropathy gene therapy clinical trial recruitment: year 1. Arch Ophthalmol. 2010;128(9):1129-1135.

184. Ying M, Xu R, Wu X, et al. Sodium butyrate ameliorates histone hypoacetylation and neurodegenerative phenotypes in a mouse model for DRPLA. J Biol Chem. 2006;281(18):12580-12586.

185. Gardian G, Browne SE, Choi DK, et al. Neuroprotective effects of phenylbutyrate in the N171-182Q transgenic mouse model of Huntington's disease. J Biol Chem. 2005;280(1):556-563.

186. Minamiyama M, Katsuno M, Adachi H, et al. Sodium butyrate ameliorates phenotypic expression in a transgenic mouse model of spinal and bulbar muscular atrophy. Hum Mol Genet. 2004;13(11): 1183-1192.

187. Zhou W, Bercury K, Cummiskey J, Luong N, Lebin J, Freed CR. Phenylbutyrate up-regulates the DJ-1 protein and protects neurons in cell culture and in animal models of Parkinson disease. J Biol Chem. 2011;286(17):14941-14951.

188. Gardian G, Yang L, Cleren C, Calingasan NY, Klivenyi P, Beal MF Neuroprotective effects of phenylbutyrate against MPTP neurotoxicity. Neuromolecular Med. 2004;5(3):235-241.

189. Jeng YY, Lin NT, Chang PH, et al. Retinal ischemic injury rescued by sodium 4-phenylbutyrate in a rat model. Exp Eye Res. 2007;84(3): 486-492.

190. Clements CM, McNally RS, Conti BJ, Mak TW, Ting JP. DJ-1, a cancer- and Parkinson's disease-associated protein, stabilizes the antioxidant transcriptional master regulator Nrf2. Proc Natl Acad Sci U S A. 2006;103(41):15091-15096. 
191. Thomas KJ, McCoy MK, Blackinton J, et al. DJ-1 acts in parallel to the PINK1/parkin pathway to control mitochondrial function and autophagy. Hum Mol Genet. 2011;20(1):40-50.

192. Irrcher I, Aleyasin H, Seifert EL, et al. Loss of the Parkinson's diseaselinked gene DJ-1 perturbs mitochondrial dynamics. Hum Mol Genet. 2010;19(19):3734-3746.

193. Wilson BJ, Tremblay AM, Deblois G, Sylvain-Drolet G, Giguere V. An acetylation switch modulates the transcriptional activity of estrogenrelated receptor alpha. Mol Endocrinol. 2010;24(7):1349-1358.

194. Scarpulla RC. Transcriptional activators and coactivators in the nuclear control of mitochondrial function in mammalian cells. Gene. 2002; 286(1):81-89.

195. Cammarata PR, Chu S, Moor A, Wang Z, Yang SH, Simpkins JW. Subcellular distribution of native estrogen receptor alpha and beta subtypes in cultured human lens epithelial cells. Exp Eye Res. 2004;78(4):861-871.

196. Yang SH, Liu R, Perez EJ, et al. Mitochondrial localization of estrogen receptor beta. Proc Natl Acad Sci U S A. 2004;101(12):4130-4135.

197. Mattingly KA, Ivanova MM, Riggs KA, Wickramasinghe NS, Barch MJ, Klinge CM. Estradiol stimulates transcription of nuclear respiratory factor-1 and increases mitochondrial biogenesis. Mol Endocrinol. 2008;22(3):609-622.

198. Chen JQ, Eshete M, Alworth WL, Yager JD. Binding of MCF-7 cell mitochondrial proteins and recombinant human estrogen receptors alpha and beta to human mitochondrial DNA estrogen response elements. J Cell Biochem. 2004;93(2):358-373.

199. Hsieh YC, Yu HP, Suzuki T, et al. Upregulation of mitochondrial respiratory complex IV by estrogen receptor-beta is critical for inhibiting mitochondrial apoptotic signaling and restoring cardiac functions following trauma-hemorrhage. J Mol Cell Cardiol. 2006; 41(3):511-521.

200. Giordano C, Montopoli M, Perli E, et al. Oestrogens ameliorate mitochondrial dysfunction in Leber's hereditary optic neuropathy. Brain. 2011;134(Pt 1):220-234.

201. Moor AN, Gottipati S, Mallet RT, et al. A putative mitochondrial mechanism for antioxidative cytoprotection by 17 beta-estradiol. Exp Eye Res. 2004;78(5):933-944.

202. Gorres BK, Bomhoff GL, Morris JK, Geiger PC. In vivo stimulation of oestrogen receptor increases insulin-stimulated skeletal muscle glucose uptake. J Physiol. 2011;589(Pt 8):2041-2054.

203. Rogers NH, Witczak CA, Hirshman MF, Goodyear LJ, Greenberg AS. Estradiol stimulates Akt, AMP-activated protein kinase (AMPK) and TBC1D1/4, but not glucose uptake in rat soleus. Biochem Biophys Res Commun. 2009;382(4):646-650.

204. Schulz E, Anter E, Zou MH, Keaney JF Jr. Estradiol-mediated endothelial nitric oxide synthase association with heat shock protein 90 requires adenosine monophosphate-dependent protein kinase. Circulation. 2005;111(25):3473-3480.

205. Simpkins JW, Yi KD, Yang SH, Dykens JA. Mitochondrial mechanisms of estrogen neuroprotection. Biochim Biophys Acta. 2010; 1800(10):1113-1120.

206. Russo R, Cavaliere F, Watanabe C, et al. 17-Beta-estradiol prevents retinal ganglion cell loss induced by acute rise of intraocular pressure in rat. Prog Brain Res. 2008;173:583-590.

207. Deschenes MC, Descovich D, Moreau M, et al. Postmenopausal hormone therapy increases retinal blood flow and protects the retinal nerve fiber layer. Invest Ophthalmol Vis Sci. 2010;51(5): 2587-2600.

208. Nilsen J, Diaz Brinton R. Mechanism of estrogen-mediated neuroprotection: regulation of mitochondrial calcium and $\mathrm{Bcl}-2$ expression. Proc Natl Acad Sci U S A. 2003;100(5):2842-2847.

209. Lee S, Van Bergen NJ, Kong GY, et al. Mitochondrial dysfunction in glaucoma and emerging bioenergetic therapies. Exp Eye Res. 2010;2:93-100.

210. Kim I, Rodriguez-Enriquez S, Lemasters JJ. Selective degradation of mitochondria by mitophagy. Arch Biochem Biophys. 2007;462(2): $245-253$.
211. Goldman SJ, Taylor R, Zhang Y, Jin S. Autophagy and the degradation of mitochondria. Mitochondrion. 2010;10(4):309-315.

212. Wenz T, Williams SL, Bacman SR, Moraes CT. Emerging therapeutic approaches to mitochondrial diseases. Dev Disabil Res Rev. 2010; 16(2):219-229.

213. Puigserver P, Spiegelman BM. Peroxisome proliferator-activated receptor-gamma coactivator 1 alpha (PGC-1 alpha): transcriptional coactivator and metabolic regulator. Endocr Rev. 2003;24(1): 78-90.

214. Canto C, Auwerx J. PGC-1alpha, SIRT1 and AMPK, an energy sensing network that controls energy expenditure. Curr Opin Lipidol. 2009; 20(2):98-105.

215. Aoun P, Simpkins JW, Agarwal N. Role of PPAR-gamma ligands in neuroprotection against glutamate-induced cytotoxicity in retinal ganglion cells. Invest Ophthalmol Vis Sci. 2003;44(7):2999-3004.

216. Zhao Y, Patzer A, Gohlke P, Herdegen T, Culman J. The intracerebral application of the PPARgamma-ligand pioglitazone confers neuroprotection against focal ischaemia in the rat brain. Eur J Neurosci. 2005;22(1):278-282.

217. Culman J, Zhao Y, Gohlke P, Herdegen T. PPAR-gamma: therapeutic target for ischemic stroke. Trends Pharmacol Sci. 2007;28(5): 244-249.

218. Fong WH, Tsai HD, Chen YC, Wu JS, Lin TN. Anti-apoptotic actions of PPAR-gamma against ischemic stroke. Mol Neurobiol. 2010;41(2-3): 180-186.

219. Fehm HL, Kern W, Peters A. The selfish brain: competition for energy resources. Prog Brain Res. 2006;153:129-140.

220. Kahn BB, Alquier T, Carling D, Hardie DG. AMP-activated protein kinase: ancient energy gauge provides clues to modern understanding of metabolism. Cell Metab. 2005;1(1):15-25.

221. Hardie DG. AMP-activated/SNF1 protein kinases: conserved guardians of cellular energy. Nat Rev Mol Cell Biol. 2007;8(10):774-785.

222. Poels J, Spasic MR, Callaerts P, Norga KK. Expanding roles for AMP-activated protein kinase in neuronal survival and autophagy. Bioessays. 2009; 31(9):944-952.

223. Sugden C, Crawford RM, Halford NG, Hardie DG. Regulation of spinach SNF1-related (SnRK1) kinases by protein kinases and phosphatases is associated with phosphorylation of the T loop and is regulated by 5'-AMP. Plant J. 1999;19(4):433-439.

224. Fryer LG, Parbu-Patel A, Carling D. The anti-diabetic drugs rosiglitazone and metformin stimulate AMP-activated protein kinase through distinct signaling pathways. J Biol Chem. 2002;277(28): 25226-25232.

225. Fulco M, Sartorelli V. Comparing and contrasting the roles of AMPK and SIRT1 in metabolic tissues. Cell Cycle. 2008;7(23): 3669-3679.

226. Correia S, Carvalho C, Santos MS, et al. Metformin protects the brain against the oxidative imbalance promoted by type 2 diabetes. Med Chem. 2008;4(4):358-364.

227. El-Mir MY, Detaille D, R-Villanueva G, et al. Neuroprotective role of antidiabetic drug metformin against apoptotic cell death in primary cortical neurons. J Mol Neurosci. 2008;34(1):77-87.

228. Pfister JA, Ma C, Morrison BE, D’Mello SR. Opposing effects of sirtuins on neuronal survival: SIRT1-mediated neuroprotection is independent of its deacetylase activity. PLoS One. 2008;3(12):e4090.

229. Brunet A, Sweeney LB, Sturgill JF, et al. Stress-dependent regulation of FOXO transcription factors by the SIRT1 deacetylase. Science. 2004;303(5666):2011-2015.

230. Civitarese AE, Carling S, Heilbronn LK, et al. Calorie restriction increases muscle mitochondrial biogenesis in healthy humans. PLoS Med. 2007;4(3):e76.

231. Shindler KS, Ventura E, Rex TS, Elliott P, Rostami A. SIRT1 activation confers neuroprotection in experimental optic neuritis. Invest Ophthalmol Vis Sci. 2007;48(8):3602-3609.

232. Lopez-Lluch G, Hunt N, Jones B, et al. Calorie restriction induces mitochondrial biogenesis and bioenergetic efficiency. Proc Natl Acad Sci U SA. 2006;103(6):1768-1773. 
233. Nisoli E, Tonello C, Cardile A, et al. Calorie restriction promotes mitochondrial biogenesis by inducing the expression of eNOS. Science. 2005;310(5746):314-317.

234. Descamps O, Riondel J, Ducros V, Roussel AM. Mitochondrial production of reactive oxygen species and incidence of age-associated lymphoma in OF1 mice: effect of alternate-day fasting. Mech Ageing Dev. 2005;126(11):1185-1191.

235. Kawai SI, Vora S, Das S, Gachie E, Becker B, Neufeld AH. Modeling of risk factors for the degeneration of retinal ganglion cells after ischemia/reperfusion in rats: effects of age, caloric restriction, diabetes, pigmentation, and glaucoma. FASEB J. 2001;15(7):1285-1287.

236. Fulco M, Cen Y, Zhao P, et al. Glucose restriction inhibits skeletal myoblast differentiation by activating SIRT1 through AMPK-mediated regulation of Nampt. Dev Cell. 2008;14(5):661-673

237. Guarente L. Connecting the dots: Linking sirtuins and AMPK in metabolism and aging. Dev Cell. 2011;20(4):e1.

238. Zang M, Xu S, Maitland-Toolan KA, et al. Polyphenols stimulate AMP-activated protein kinase, lower lipids, and inhibit accelerated atherosclerosis in diabetic LDL receptor-deficient mice. Diabetes 2006;55(8):2180-2191.

239. Dasgupta B, Milbrandt J. Resveratrol stimulates AMP kinase activity in neurons. Proc Natl Acad Sci U S A. 2007;104(17):7217-7222.

240. Lagouge M, Argmann C, Gerhart-Hines Z, et al. Resveratrol improves mitochondrial function and protects against metabolic disease by activating SIRT1 and PGC-1alpha. Cell. 2006;127(6):1109-1122.

241. Parker JA, Arango M, Abderrahmane S, et al. Resveratrol rescues mutant polyglutamine cytotoxicity in nematode and mammalian neurons. Nat Genet. 2005;37(4):349-350.

242. Luna C, Li G, Liton PB, et al. Resveratrol prevents the expression of glaucoma markers induced by chronic oxidative stress in trabecular meshwork cells. Food Chem Toxicol. 2009;47(1):198-204.

243. King RE, Kent KD, Bomser JA. Resveratrol reduces oxidation and proliferation of human retinal pigment epithelial cells via extracellular signal-regulated kinase inhibition. Chem Biol Interact. 2005;151(2) 143-149.

244. Quinzii CM, Lopez LC, Naini A, DiMauro S, Hirano M. Human CoQ10 deficiencies. Biofactors. 2008;32(1-4):113-118.
245. Rodriguez MC, MacDonald JR, Mahoney DJ, Parise G, Beal MF, Tarnopolsky MA. Beneficial effects of creatine, CoQ10, and lipoic acid in mitochondrial disorders. Muscle Nerve. 2007;35(2):235-242.

246. Stacpoole PW dT, Feigenbaum AS, Kerr DS. Phase III trial of coenzyme Q10 in mitochondrial disease. www.clinicaltrials.gov, NCT00432744

247. Hirano M, Engelstad K, Jerome R. Study of Idebenone in the treatment of Mitochondrial Encephalopathy Lactic Acidosis and Stroke-Like Episodes (MELAS), www.clinicaltrials.gov, NCT00887562.

248. Kerr DS. Treatment of mitochondrial electron transport chain disorders: a review of clinical trials over the past decade. Mol Genet Metab. 2010;99(3):246-255.

249. Meier T, Buyse G. Idebenone: an emerging therapy for Friedreich ataxia. J Neurol. 2009;256 Suppl 1:25-30.

250. Schulz JB, Di Prospero NA, Fischbeck K. Clinical experience with high-dose idebenone in Friedreich ataxia. J Neurol. 2009;256 Suppl 1:42-45

251. Mashima Y, Kigasawa K, Wakakura M, Oguchi Y. Do idebenone and vitamin therapy shorten the time to achieve visual recovery in Leber hereditary optic neuropathy? J Neuroophthalmol. 2000;20(3): $166-170$

252. Carelli V, Barboni P, Zacchini A, et al. Leber's hereditary optic neuropathy (LHON) with 14484/ND6 mutation in a North African patient. J Neurol Sci. 1998;160(2):183-188.

253. Barnils N, Mesa E, Munoz S, Ferrer-Artola A, Arruga J. Response to idebenone and multivitamin therapy in Leber's hereditary optic neuropathy. Arch Soc Esp Oftalmol. 2007;82(6):377-380. Spanish.

254. Rouleau JKT, Chinnery P. Study to assess efficacy, safety and tolerability of idebenone for Leber's hereditary optic neuropathy, www.clinicaltrials.gov, NCT00747487.

255. Barboni P, La Morgia C, Carbonelli M, et al. Recovery of visual acuity in dominant optic atrophy after idebenone treatment. Presented at the Association for Research in Vision and Ophthalmology Visionary Genomics meeting. Fort Lauderdale, FL, May 1-5, 2011.
Eye and Brain

\section{Publish your work in this journal}

Eye and Brain is an international, peer-reviewed, open access journa focusing on clinical and experimental research in the field of neuro-ophthalmology. All aspects of patient care are addressed within the journal as well as basic research. Papers covering original research, basic science, clinical and epidemiological studies, reviews and evaluations,

\section{Dovepress}

guidelines, expert opinion and commentary, case reports and extended reports are welcome. The manuscript management system is completely online and includes a very quick and fair peer-review system, which is all easy to use. Visit http://www.dovepress.com/testimonials.php to read real quotes from published authors. 